\title{
Anthropogenic intensification of short- duration rainfall extremes
}

Article

Accepted Version

Fowler, H. J., Lenderink, G., Prein, A. F., Westra, S., Allan, R. ORCID: https://orcid.org/0000-0003-0264-9447, Ban, N., Barbero, R., Berg, P., Blenkinsop, S., Do, H. X., Guerreiro, S. B., Haerter, J. O., Kendon, E., Lewis, E., Schaer, C., Sharma, A., Villarini, G., Wasko, C. and Zhang, X. (2021) Anthropogenic intensification of short-duration rainfall extremes. Nature Reviews Earth \& Environment, 2. pp. 107122. ISSN 2662-138X doi: https://doi.org/10.1038/s43017-02000128-6 Available at https://centaur.reading.ac.uk/95124/

It is advisable to refer to the publisher's version if you intend to cite from the work. See Guidance on citing.

Published version at: http://dx.doi.org/10.1038/s43017-020-00128-6

To link to this article DOI: http://dx.doi.org/10.1038/s43017-020-00128-6

Publisher: Nature

All outputs in CentAUR are protected by Intellectual Property Rights law, including copyright law. Copyright and IPR is retained by the creators or other copyright holders. Terms and conditions for use of this material are defined in the End User Agreement. 


\section{CentAUR}

Central Archive at the University of Reading

Reading's research outputs online 


\section{Anthropogenic intensification of short-duration rainfall extremes}

Hayley J. Fowler ${ }^{1 \dagger}$, Geert Lenderink ${ }^{2}$, Andreas F. Prein ${ }^{3}$, Seth Westra ${ }^{4}$, Richard P. Allan ${ }^{5,6}$, Nikolina Ban ${ }^{7}$, Renaud Barbero ${ }^{8}$, Peter Berg ${ }^{9}$, Stephen Blenkinsop ${ }^{1}$, Hong X. Do ${ }^{10,11}$, Selma Guerreiro ${ }^{1}$, Jan O. Haerter $^{12,13,14}$, Elizabeth Kendon ${ }^{15}$, Elizabeth Lewis ${ }^{1}$, Christoph Schaer ${ }^{16}$, Ashish Sharma ${ }^{17}$, Gabriele Villarini $^{18}$, Conrad Wasko ${ }^{19}$, Xuebin Zhang ${ }^{20}$

†email: h.j.fowler@,ncl.ac.uk

1 School of Engineering, Newcastle University, Newcastle upon Tyne, UK

2 Royal Netherlands Meteorological Institute, De Bilt, the Netherlands

3 National Center for Atmospheric Research (NCAR), USA

4 School of Civil, Environmental and Mining Engineering, University of Adelaide, South Australia, Australia

5 Department of Meteorology, University of Reading, Reading, UK

6 National Centre for Earth Observations, University of Reading, Reading, UK

7 Department of Atmospheric and Cryospheric Sciences, University of Innsbruck, Innsbruck, Austria

8 National Research Institute for Agriculture, Food and Environment, RECOVER, Aix-en-Provence, France

9 Hydrology Research Unit, Swedish Meteorological and Hydrological Institute, Norrköping, Sweden 10 School for Environment and Sustainability, University of Michigan, Ann Arbor, Michigan, US

11 Faculty of Environment and Natural Resources, Nong Lam University, Ho Chi Minh City, Vietnam 12 Niels Bohr Institute, University of Copenhagen, Blegdamsvej 17, 2100 Copenhagen, Denmark

13 Complexity and Climate, Leibniz Centre for Tropical Marine Research, Fahrenheitstr. 6, 28359 Bremen, Germany,

14 Physics \& Earth Sciences, Jacobs University Bremen, Campus Ring 1, 28759 Bremen, Germany

15 Met Office Hadley Centre, Exeter, UK

16 Institute for Atmospheric and Climate Sciences, ETH Zürich, Zürich, Switzerland

17 School of Civil and Environmental Engineering, University of New South Wales, Sydney, New South Wales, Australia

18 IIHR-Hydroscience \& Engineering, The University of Iowa, Iowa City, Iowa, USA.

19 Department of Infrastructure Engineering, The University of Melbourne, Victoria, Australia

20 Climate Research Division, Environment and Climate Change Canada, Montreal, Canada

\section{Key Messages:}

- Heavy rainfall extremes are intensifying with warming at a rate generally consistent with the increase in atmospheric moisture, for accumulation periods from hours to days.

- In some regions, high-resolution modeling, observed trends and observed temperature dependencies indicate stronger increases in short-duration, sub-daily, extreme rainfall intensities, up to twice what would be expected from atmospheric moisture increases alone.

- Stronger local increases in short-duration extreme rainfall intensities are related to convective cloud feedbacks but their relevance to climate change is uncertain due to modulation by changes to temperature stratification and large-scale atmospheric circulation 
- The evidence is unclear whether storm size will increase or decrease with warming; however, increases in rainfall intensity and the spatial footprint of the storm can compound to give significant increases in the total rainfall during an event.

- Evidence is emerging that sub-daily rainfall intensification is related to an intensification of flash flooding, at least locally. This will have serious implications for flash flooding on much of the planet and requires urgent climate-change adaptation measures. 


\begin{abstract}
Short-duration ( 1 to 3 hour) rainfall extremes can cause serious damage to societies through rapidly developing (flash) flooding and are determined by complex, multifaceted processes that are altering as Earth's climate warms. In this Review, we examine evidence from observational, theoretical and modelling studies for their intensification, the drivers and the likely impacts on flash-flooding. Short-duration rainfall extremes are intensifying with warming at a rate consistent with atmospheric moisture increase $(\sim 7 \% / \mathrm{K})$ that also drives intensification of longer-duration extremes (1day+). Evidence from some regions indicates stronger increases to short-duration extreme rainfall intensities than expected from moisture increases alone. Idealized modelling studies suggest these stronger local increases are related to convective cloud feedbacks but their relevance to climate change is uncertain. Future extreme rainfall intensification is also modulated by changes to temperature stratification and large-scale atmospheric circulation. The latter remains a major source of uncertainty. Intensification of short-duration extremes has likely increased the incidence of flash flooding at local scales and this can further compound with an increased storm spatial footprint to significantly increase total event rainfall. These findings call for urgent climate-change adaptation measures to manage increasing flood risks.
\end{abstract}

\title{
1. Introduction
}

Intensification of the hydrological cycle is one of the known impacts of a warming climate, with rainfall extremes increasing over recent decades ${ }^{1,2,3}$. However, uncertainty remains in understanding changes to rainfall extremes, particularly for short-duration (1-3hr), relatively small-scale (10s of $\mathrm{km}$ or less), convective events. Changes to rainfall extremes have been assessed based on the frequency of events above a threshold or the intensity at a given frequency, often a percentile such as the $99^{\text {th }}$ or $99.9^{\text {th }}$ (or return period). While changes in frequency and intensity have the same sign, the amplitude of the change differs depending upon the shape of the rainfall distribution. Usually, changes to the frequency of the most extreme events exceed those of the intensity changes - a property which is tied to the distribution of rainfall extremes ${ }^{4}$

Central to understanding increases in extreme rainfall intensities due to warming is the Clausius-Clapeyron (CC) relation. This relation governs the saturation specific humidity of the atmosphere as a function of temperature, increasing at a rate of $\sim 7 \%$ per degree warming $\left(\mathrm{K}^{-1}\right)$ near the Earth's surface. Given that other atmospheric conditions, such as relative humidity, remain approximately constant with warming across most of the land surface, the actual humidity of the air also increases at roughly the same rate ${ }^{5,6}$. Since rainfall extremes are limited by the amount of atmospheric moisture available, changes to rainfall intensities are to a first approximation expected to scale with the CC relation ${ }^{7}$.

Several studies have confirmed an approximately CC rate of increase in observations and projections of daily extreme rainfall ${ }^{1,2,8,9,10}$ when averaged globally, while locally, substantial deviation from these scalings can be explained by changes in local meteorology. The relation between extreme daily rainfall intensities and short-term (day-to-day) variability in temperature - the 'apparent' scaling - also approximately follows the $\mathrm{CC}$ rate at most locations worldwide ${ }^{11}$. However, for sub-daily intensities some studies suggest an increased sensitivity to warming, with the existence of super-CC scaling (scaling rates larger than $7 \% \mathrm{~K}^{-1}$ ) in some locations $\mathrm{s}^{12,13,14,15,16}$. Evidence shows that physical processes, particularly related to convective clouds, can plausibly explain super-CC scaling rates. Suggested mechanisms that could lead to this enhanced sensitivity are dynamical feedbacks in cloud core updrafts ${ }^{7,17,18}$, cloud-cloud interactions driven by cold pools ${ }^{19}$ and quasi-geostrophic large-scale vertical uplifting ${ }^{20,18}$. However, it is uncertain whether this observed super-CC scaling will translate into a similar climate change sensitivity or 'climate' scaling. 
Multiple new studies have examined changes to sub-daily rainfall extremes, ranging from convectionpermitting modelling ${ }^{21,22,23,24}$ and idealized model experiments ${ }^{18}$ to assessments of observations $\mathbf{s}^{1,25}$. An effort updating the state of knowledge on the topic has been coordinated through the INTENSE (INTElligent use of climate models for adaptatioN to non-Stationary hydrological Extremes) crosscut $^{26}$ of the GEWEX (Global Energy and Water Exchanges) Hydroclimatology Panel. INTENSE has led a unique and very large-scale data collection effort for sub-daily precipitation across multiple continents (the Global Sub-Daily Rainfall (GSDR) dataset ${ }^{27}$, see Fig. 1), producing new insight into the global climatology of subdaily precipitation extremes from gauge data ${ }^{28}$. Alongside this advance has been the development of new satellite retrieval methods for precipitation and regional-scale radar datasets. Together, these datasets have been used to quantify the effects of changes in temperature and humidity on precipitation extremes at different time-scales, links between the frequency and intensity of heavy rainfall and large-scale circulation variability ${ }^{29}$ and local changes to the spatial structure of intense storms ${ }^{30}$. However, despite this new understanding from observations of present-day climate, the degree to which these observed relationships will hold in a warming climate is still unclear.

The development of very high-resolution convection-permitting model (CPM) simulations has allowed subdaily, and even sub-hourly, precipitation extremes to be represented over continental-scale areas on (multi)decadal time scales ${ }^{24,21,31,32,33}$ (see Fig. 1 for continental-scale domains available at $<5 \mathrm{~km}$ horizontal grid spacing). CPMs explicitly resolve cloud dynamical processes, providing large improvements over coarser-resolution climate models with parameterized deep convection in the simulation of sub-daily precipitation, including intensity-frequency-duration characteristics $s^{34,35,31,36}$, orographically-enhanced extreme precipitation ${ }^{37,38,35,39}$ and scaling relations ${ }^{40}$. CPM simulations use two main approaches. Firstly, pseudo-global warming ${ }^{41,42,43}$ (PGW), where a storm's environment is perturbed by mean climate change signals typically derived from Global Climate Models (GCMs). PGW is used to show how the characteristics of an extreme event (for example, a tropical cyclone) would change if it had occurred in a past (cooler and drier) or future (warmer and wetter) climate, or to create time-dependent lateral boundary conditions for downscaling with Regional Climate Models ${ }^{23,44,45}$. Secondly, full downscaling of coarserresolution climate model simulations to provide more realistic characteristics of sub-daily rainfall ${ }^{46}$ for ensembles of events or full climate-scale runs, with the CPM simulating mesoscale processes that are unresolved in the driving climate model.

The CC rate of increase in extreme rainfall intensities implied across modelling and observations has obvious implications for impacts, while super-CC scaling would have a greater effect ${ }^{47}$. Short-duration rainfall extremes are particularly hazardous and are responsible for fatalities through flash floods and landslides that occur with little warning ${ }^{48,49}$, as well as pollution incidents from combined sewerage networks ${ }^{50}$. Cities are particularly vulnerable to floods generated by heavy short-duration rainfall since their infrastructure systems were built during the last centuries based on historically lower rainfall intensities, with a subsequent increase in impermeable surfaces; this provides a need for urgent adaptation measures. Improved understanding of the intensification of extreme (particularly short-duration) rainfall is crucial for effective climate adaptation, with important implications for broader science and engineering communities in managing the water environment.

In this Review, we synthesize the literature relating to the intensification of short-duration rainfall extremes through a process-based lens, using observed trends and temperature-scaling studies together with insights from very high-resolution climate models to examine the changing characteristics of sub-daily rainfall extremes with warming and the drivers of these changes. In particular, we concentrate on bringing observational and model understanding together to describe the mechanisms of change, which was something that was not possible previously ${ }^{8}$. This allows us to propose a conceptual framework for understanding the intensification of short-duration rainfall extremes and to assess the implications for flood risks. Finally, we provide some comments about gaps in our current knowledge and how we might address these. 


\section{Temperature Scaling of Extreme Rainfall Intensities}

Since extreme rainfall changes appear to follow the increase in temperature and associated atmospheric water content, much research has concentrated on estimating scaling relations between extreme rainfall intensities and temperature from observed short-term climate variability - 'apparent' scaling ${ }^{51}$ - which might then be used as evidence to help understand how extreme rainfall will respond in a changing climate - 'climate' scaling. However, the wide variety of methodological approaches ${ }^{12,52,53,54,55}$, temperature measurements and rates (maximum, mean or interval ahead of rainfall) used complicate the interpretation of scaling results.

Studies indicate that daily extremes mainly show CC-scaling ${ }^{3,2}$ but super-CC scaling $(>7 \% / \mathrm{K})$ appears in some locations (for example Australia, the Netherlands, Hong Kong) for extreme hourly or shorter accumulations. Fig. 2 illustrates these apparent scaling relationships for the Netherlands. Scaling strongly depends on the temperature measurements used, with near-surface air temperature commonly producing $\mathrm{CC}$ or super-CC scaling rates for hourly rainfall at low to moderate temperatures (from $10-20{ }^{\circ} \mathrm{C}$ ), but negative rates at moderate to high temperatures $\left(>20-25^{\circ} \mathrm{C}\right)^{56,57,8,58}$. Negative scaling at high near-surface air temperatures is (partly) explained by drier conditions necessary to generate the hottest temperatures and limited moisture availability on warm days ${ }^{12,59,60,16,14}$, where high-pressure situations are characterized by high temperatures and low (relative) humidity ${ }^{40,61}$. Including moisture in the assessment ${ }^{60}$, by use of dewpoint temperature ${ }^{59}$ (Fig. 3a), produces greater consistency in scaling across regions and temperature regimes, with dependencies close to CC or above, even in the Tropics ${ }^{11,13,14,62,63}$.

The use of temperature-scaling to project change to extreme precipitation with future warming is complex ${ }^{64,51}$. Understanding the processes behind super-CC scaling may allow the exclusion of systematic dependencies not relevant for climate scaling. For example, present day scaling may alias changes in meteorological regimes (e.g. stratiform to convective rain types) with temperature ${ }^{15,65}$ (see Fig. 3b) or the mixing of large-scale and local forcing, particularly if large-scale flow conditions vary substantially between seasons ${ }^{64,66}$. The reversal of causal relations whereby intense rainfall is itself the cause of temperature variations ${ }^{51,60,59,67}$ may also influence apparent scaling. Despite these complications, temperature-scaling may perhaps be expected to be similar for short-term variability and future (and past ${ }^{13}$ ) warming when sampling consistent meteorological regimes and by considering the influence of moisture and latent heat release $\mathrm{e}^{17,68}$. However, changes to temperature stratification in the atmosphere and to largescale (or even mesoscale) circulation variability ${ }^{69,70}$ can also strongly affect extreme precipitation intensities but are not strongly connected to apparent temperature-scaling.

\section{Changing character of sub-daily rainfall extremes}

\subsection{Changes to extreme rainfall intensity}

A growing number of observational analyses point to increases in the frequency and/or intensity of subdaily (primarily hourly) rainfall extremes in, for example, Australia ${ }^{1}$, parts of China ${ }^{71}$, SE Asia ${ }^{72}$, Europe $^{73,74}$, and North America ${ }^{75}$. Fig. 4 updates ${ }^{8,76}$ and summarizes existing analyses of change from rain gauge observations. The understanding of changes across large areas of the globe has been inhibited by either a lack of data or lack of access to it and, even where data exists, the nature and extent of quality control checks on sub-daily rainfall data is not always apparent. Further, a significant minority of studies identified in Fig. 4 only consider local-scale changes ${ }^{77}$ based on a small selection of gauges and thus may not adequately represent regional-scale changes. Results published to date are also not directly comparable with each other due to the application of a wide range of different methodologies (for example, linear trends, extreme value theory), different metrics (for example, percentile-based, peaks-over-threshold, return 
periods), and different periods of analysis (for example, length of records, annual/seasonal). This includes, in some instances, the use of relatively short periods of observations which means results may be sensitive to natural variability rather than representative of long-term change ${ }^{78}$. The predominantly positive trends over the U.S., Europe and Australia are consistent with the earlier initial review ${ }^{8}$; however, the previously identified positive regional trends indicated over South Africa are no longer robust across studies. A pattern of regionally varying change remains over China, although we now see evidence of increases over most of eastern China and decreases in the north. Several new studies also point to increases over southeast Asia, but across the U.K., the Republic of Ireland and Canada, despite multiple studies, no conclusive signal has emerged.

Linear trend techniques remain the most common method of analysis (typically through application of a Mann-Kendall test) but are not necessarily appropriate for extreme precipitation, which is unlikely to show a linear response, even to strong forcing ${ }^{79} 80$. Furthermore, even where trends are examined across regional and national scales, few studies consider the field significance of any observed changes (see ${ }^{75}$ for an example of field significance testing). Thus, identifying the most appropriate methodologies for robust detection of rainfall change emerges as a significant issue. Although many observation-based change detection studies identify and discuss warming as a potential mechanism for increased event frequency/intensity, relatively few actually test this hypothesis, or consider observed changes in the context of other potential drivers ${ }^{78}$. Figure 4 therefore identifies studies where sub-daily rainfall trends/changes are analyzed in the context of either observed temperature change or scaling ${ }^{13}$, large-scale circulation and modes of variability ${ }^{78}$, or the potential influence of urbanization, through increases in anthropogenic aerosols ${ }^{81}$ or the urban heat island effect ${ }^{82}$, which is emerging as an interesting research area.

In some studies, intensification has been shown to exceed thermodynamic expectations. For instance, peak intensities of extreme hourly rainfall are intensifying more rapidly than would be expected with global mean warming in Australia ${ }^{1}$, at up to 3 times the $\mathrm{CC}$ rate. Although land is warming faster than the global mean, allowing faster rises in saturation specific humidity, this effect is not expected to enhance moisture increases over land since the ultimate source of moisture is primarily the oceans which are warming closer to the global mean rate. Other studies have corroborated this super-CC intensification ${ }^{25,18,83}$, albeit with potentially low statistical certainty due to short record lengths ${ }^{84}$. Evidence has also been found, mainly in tropical locations, for a strengthening of precipitation systems and significant effects of warming on peak intensities in urban areas ${ }^{85,86}$, with intensification of peak intensities and frequencies of hourly extreme precipitation tending to occur downwind of urban areas in mid-latitude locations such as the US Mid-west ${ }^{87}$.

Results from convection-permitting models corroborate these observed trends. Most CPM studies project higher intensification of sub-daily rainfall extremes than convection-parameterized models, with intensification almost always at or above the CC scaling rate en $21,22,23,24,88,89,90,91,92$. Mesoscale models also find super-CC scaling of future intensities ${ }^{68}$. Furthermore, there is increasing evidence from CPMs that the peak intensities and frequencies of very rare, high impact rainfall extremes will increase at a faster rate with warming ${ }^{23,93}$. At the same time, moderate and light rainfall hours are projected to decrease in frequency ${ }^{94}$, resulting in future climates that are more favorable for both droughts and floods concurrently ${ }^{22,24,95,96}$. This relation is physically understandable since global precipitation is constrained by the global energy budget to increase more slowly than extreme precipitation thereby requiring sub-CC or even decreases in precipitation away from the wet regimes ${ }^{97}$; an observational study ${ }^{98}$ also found more intense peak rainfall at the expense of total rainfall at higher temperatures in Australia, regardless of the climatic region and season.

PGW simulations have shown that extreme rainfall from tropical cyclones is already higher than during pre-industrial conditions and will likely continue to intensify under future warming at rates that are potentially higher than the CC scaling $91,99,100,101,102,103$. Similar results have been found for flood-producing mesoscale convective systems ${ }^{104,105,106}$ (MCSs) in the U.S. and extreme rainfall in the Netherlands which 
feature super-CC increases ${ }^{107,108}$. These large increases have been partly related to more vigorous updrafts in the U.S. cases, but assessing uncertainties in convection-permitting simulations remains challenging

Differences in statistical approaches (for example, using conditional percentiles ${ }^{55}$ ) account for at least part of the spread in projections of future intensification from different modelling studies, but the region and dominant precipitation type (for example, convective vs orographic) also likely play an important role. Despite this, the signal of extreme rainfall intensification is robust across different climate types, latitudes and CPM structures ${ }^{109}$. CPM simulations indicate that sub-daily rainfall extremes are likely to intensify in regions and seasons where moisture supply is not limited ${ }^{23,110}$. However, a fixed temperature threshold above which precipitation is limited by moisture availability is not supported by modelling evidence $e^{4,23}$.

\subsection{Changes to storm structures}

Other characteristics of extreme storms, besides rainfall intensity, are equally important for flooding but have not been studied extensively so far. Observational studies indicate that for warmer temperatures, precipitation events increase their peak intensity and become smaller in size in Australia ${ }^{111}$ and Germany ${ }^{112}$ but increase their peak intensity and become larger in the Netherlands ${ }^{30}$. This increase in storm size with climate warming is also shown in CPM pseudo-warming experiments for the U.S. ${ }^{95}$. For the UK, CPM simulations show peak intensity increases and storms becoming longer in duration with warming ${ }^{32}$ although spatial aspects of storms were not examined. However, it should be noted that the duration at a given location is related to the spatial size of the storm multiplied by its propagation speed.

Studies focusing on MCSs in North America have shown that CPMs can capture MCS size, movement speed, and evolution ${ }^{104,113}$. MCSs are the main cause of extreme precipitation in the eastern U.S. ${ }^{114}$. Hourly rainfall volumes from extreme MCSs might increase at much faster rates than CC due to a combination of close to CC increases in hourly peak rainfall rates and a spread of the heavy rainfall area ${ }^{95}$. This increase in peak intensities and spatial footprint of storms in a warming climate might result in even higher increases in total 'event' rainfal195,99. Increased moisture advection into future MCSs and changes in the cloud microphysics are possible causes for the rapid increase in precipitation volume but further work is needed to understand the robustness of these results. The amplitude of the diurnal cycle of surface temperature, not just its mean or maximum, might also help MCSs to develop ${ }^{115}$.

\section{Disentangling drivers of change}

The rate of intensification of rainfall extremes under climate change depends on various processes that range from micro- to synoptic- and planetary-scales. New observational and CPM studies have enhanced our understanding of how these processes interact and how they might affect future extreme rainfall. Thermodynamic changes on their own - considering only direct humidity effects - result in an intensification of sub-daily rainfall extremes, which is close to or slightly below CC scaling ${ }^{23,99,105}$. However, enhancing or damping this increase are several dynamical changes at small and large scales ${ }^{69}$. Idealized model experiments ${ }^{17,18}$ and CPMs in pseudo-global warming experiments ${ }^{107,108,68}$ indicate feedbacks through enhanced latent heating with warming can lead to a super-CC response ${ }^{116,117,17}$ for short-duration rainfall extremes. However, this response also depends strongly on stability changes of the atmosphere ${ }^{44,118}$, with closer to CC dependencies and no evidence for dynamical invigoration of precipitation extremes when atmospheric stability changes follow a moist adiabatic lapse rate ${ }^{17,119,120}$. Storm intensification at the cloudscale combined with stability increases at larger time- and space-scales thus suggest extreme rainfall responses to warming are time and space dependent ${ }^{121}$. We therefore split our explanation of process interactions into three parts, dependent on spatial scale. Fig. 5 provides a schematic summarizing our new understanding of feedback processes affecting rainfall extremes and the key findings, mainly from model projections. 


\subsection{Cloud-Scale Dynamics and Microphysics}

Atmospheric stability (vertical lapse rate) plays a key role in how convective systems respond to climate change. The intensity of convective storms is related to the Convective Available Potential Energy (CAPE) in both $\mathrm{CPMs}^{122,123,124}$ and observations ${ }^{28}$. Climate models ${ }^{125}$ and radiative-convective equilibrium modelling experiments ${ }^{126,127,128}$ project that CAPE will increase thermodynamically with warming, implying strong increases in the future frequency of occurrence of environments conducive to intense thunderstorms ${ }^{129}$. This increase in CAPE implies systematic deviation of the thermal stratification of the atmosphere from a moist adiabatic lapse rate that is non-negligible at high temperatures ${ }^{126}$. Increased CAPE, reflecting larger buoyancy in convective clouds resulting from enhanced latent heating, could then lead to super-CC behaviour ${ }^{16,117,17}$; yet evidence for stronger updrafts is still limited. However, even when CAPE and updraft velocities increase with warming, precipitation extremes may not produce super-CC scaling because the vertical profile of motion matters ${ }^{130,131}$. Urban heat islands also have an effect on extreme rainfall intensities, creating a more unstable atmosphere, increased vertical uplift and moisture convergence, sustaining a local circulation initiated by the relative warmth of the urban area ${ }^{132}$.

However, thermodynamic increases in stability and reduced continental relative humidity ${ }^{133}$ increase convective inhibition and prevent low-level buoyant air from ascending ${ }^{96,134}$. Cloud mixing could lead to smaller changes in buoyancy than CAPE changes would imply ${ }^{126}$. This effect will suppress weak and moderately intense convection from forming due to more effective entrainment reducing buoyancy in a warmer atmosphere ${ }^{126}$, although the intensity of strong convection ${ }^{24}$ may be enhanced due to stronger organization and a smaller effective entrainment. However, changes to entrainment under future warming and its effect on extreme precipitation are not well understood. CPM simulations underestimate cloud entrainment processes ${ }^{135}$, resulting in too strong updrafts and too high precipitation intensities at the surface ${ }^{136,137}$. Idealized modeling results show that resolving entrainment demands large-eddy simulation ${ }^{138}$ (LES, grid spacings $\sim 200 \mathrm{~m}$ ). Simulating entrainment processes realistically is critical to preserve realistic cloud properties and therefore for rainfall even more so under conditions of decreasing relative humidity in a future climate ${ }^{139}$.

Climate change will also affect the cloud microphysics ${ }^{140}$. The more intense convection in future climates will result in a higher ratio of graupel and hail in the cloud ${ }^{46,95,141}$, which can enhance downdraft velocities and precipitation rates. Since hail and graupel will develop at higher altitudes but encounter enhanced melting before reaching the surface due to an increase in the tropospheric melting level height ${ }^{46,95}$, this will likely increase the liquid water content in future clouds, resulting in a more active warm rain process and enhanced surface precipitation ${ }^{45}$. However, uncertainties remain: the process might be different for different regions (for example, the tropics), and probably also depends on model microphysics scheme. Modelling evidence has shown that increases in convective rainfall extremes are partly controlled by microphysical processes involving droplet/ice fall speeds; super-CC scaling could hence be the result of differences in ice/liquid fall speeds ${ }^{142,140}$. Changes in precipitation efficiency are also closely related to changes in cloud microphysics, changes in entrainment, and convection dynamics. A study on precipitation efficiency at convective scales for a long record of observations in the tropics ${ }^{143}$ found that precipitation efficiency increases with precipitation rate and mid-tropospheric humidity and decreases with increasing CAPE and surface temperature. However, these efficiency differences do not directly translate to changes in precipitation intensity due to compensating changes in cloud updraft velocities ${ }^{143}$. Climate change effects of precipitation efficiency are uncertain, with changes in efficiency found at different temperatures ${ }^{142}$ and some evidence of increases in efficiency with warming in small domains, although this is complicated by changes to convective organisation ${ }^{144}$.

Cold pools appear to be a crucial part of the dynamics of convective clouds and how they respond to warming ${ }^{145}$. Changes in downdraughts are related to changes in cold pool strength ${ }^{146}$ with wider and deeper 
clouds developing as a result of stronger cold pool dynamics ${ }^{19,147}$. Cold pools also likely mediate the "communication" between convective clouds, and thereby the initiation of new convective cells through the interaction by mechanical or thermodynamic lifting at locations of gust front collisions. There may be an explicit link between convective organization and the emergence of extreme convective events over scales beyond that of a single convective cloud through cold pools ${ }^{148}$. Climate change impacts on cold pool characteristics are highly uncertain and their impacts on extreme rainfall are not well understood (Prein et al. accepted). Furthermore, convective organization has been found to be related to a complex interaction between cold pool dynamics and vertical wind shear ${ }^{145,149}$. Vertical wind shear is expected to decrease with climate change ${ }^{150,151}$ but the resulting consequences for convective organization and extreme precipitation frequency and intensity are not well understood.

\subsection{Cloud Feedbacks and Size Effects}

Cloud-feedbacks and cloud-size effects have been shown to be important in super-CC scaling in several studies. Cloud systems merging into larger clouds (or rain areas) have been found to produce larger precipitation intensities ${ }^{30,152,153}$, with increasing height of the tropopause with climate warming allowing the establishment of larger storm systems ${ }^{154,18}$. Since high rainfall intensities can be sustained only when sufficient moisture is supplied to the cloud - noting that a typical atmospheric column only contains between $20-40 \mathrm{~mm}$ of water in the form of vapor - it is clear that horizontal moisture convergence must increase at high temperatures to support super-CC behavior. Evidence suggests that enhanced moisture convergence is strongly linked to the growth of cold pools that are formed due to cold air downdraughts caused by evaporating rain ${ }^{155,152}$, or to large-scale moisture convergence ${ }^{18,20}$. Therefore, latent heat release, increased vertical velocities and subsequent in-cloud lateral moisture convergence through the cloud base play a key role in the intensification and size of individual storms ${ }^{15,24,156,20,95,157}$ and explain a diversity of responses in standard-resolution climate model projections ${ }^{158}$.

Although storm size is related to moisture convergence, some evidence suggests intensification of the core of a convective storm at the expense of rain intensities outside the core. This can result in a disproportional intensification of the storm center at high temperatures at the expense of the rain-cell area ${ }^{12,111,159}$, also seen as a result of the urban heat island effect ${ }^{132}$. Yet, in a study using radar-based rainfall data for the Netherlands this effect could not be found, and storm center intensification and storm size went hand-inhand $^{30}$. Very-high-resolution idealized model simulations also provide evidence of stronger growth of convective cells at higher dew point temperatures ${ }^{160,155}$. So, the existence of super-CC scaling and rain-cell or storm size is likely connected, and super-CC dependencies can only be supported when large-scale conditions allow the sufficient growth of rain cells converging more moisture into the cloud system ${ }^{30}$.

There are two potential effects of storm size on short-duration extreme rainfall. In order to sustain super$\mathrm{CC}$ rates in a warmer climate, the cloud system has to source its moisture from larger areas. Thus, bigger systems with stronger dynamics draw in more moisture from the environment ${ }^{95}$. The other effect is that at a fixed surface position, a bigger system may produce more rain, so even if the intensity scales with CC, the total rainfall over a point may exceed $\mathrm{CC}^{32}$.

\subsection{Large-Scale Stability, Humidity and Dynamics}

Large-eddy simulations demonstrate that rainfall intensity depends on atmospheric stability, with a decrease in intensity as the atmosphere stabilizes, and that large-scale moisture convergence mainly governs storm size $^{154}$. Therefore, a climate change-induced stabilization of the troposphere (the decrease in temperature with height becomes smaller ${ }^{161}$ ) is expected to slow the rate of intensification of convective storms and rainfall extremes ${ }^{17,162}$. High resolution, idealized and large ensemble modelling studies demonstrate that 
enhanced latent heating of the atmosphere in warmer conditions can suppress convection at largerscales ${ }^{122,24,154}$ leading to an overall reduction in precipitation amounts, but PGW case-studies indicate that extreme rainfall events may still intensify ${ }^{10}$.

Atmospheric stability is also influenced by the direct radiative heating effect of higher $\mathrm{CO}_{2}$ concentrations ${ }^{163}$ as well as the effects of aerosols ${ }^{164}$. Warming from increased radiative forcing from declining aerosol is expected to intensify rainfall ${ }^{165}$, although the role of radiative forcings is difficult to separate from natural variability ${ }^{166}$. At local scales, atmospheric heating by absorbing aerosol and the increase in cloud condensation nuclei associated with absorbing and scattering aerosol have been linked with inhibition of warm rain and a delay and invigoration of intense rainfall and flooding ${ }^{164,167}$. The multiple processes governing future changes in atmospheric aerosol concentrations and their effects on heavily precipitating storms are highly uncertain ${ }^{164,168}$. Thus, atmospheric stability changes, which are expected to be dependent on latitude, may well play a key role in the behavior of rainfall extremes in the future climate, as also shown in CPMs ${ }^{122,24}$. In the tropics, it is well recognized that the warming profile will be closer to moist adiabatic than constant, although moist adiabatic stratification is likely to be relevant in the midlatitudes on days of heavy precipitation as well. A well understood consequence of climate change is an increase in tropopause height due to the thermal expansion of the troposphere and cooling of the stratosphere ${ }^{169}$. This increase will result in a deepening of deep convection ${ }^{170}$, which potentially increases surface precipitation ${ }^{171}$. The average low-level relative humidity is projected to decrease over most land areas ${ }^{172,133}$, which can significantly reduce heavy rainfall rates ${ }^{139}$. However, relative humidity might not change in extreme precipitation environments that typically feature moisture advection from humid regions ${ }^{95}$. Decreases in relative humidity will influence cold pool dynamics by promoting evaporation of rain, and increasing convection inhibition and atmospheric instability, thereby impacting on convective dynamics.

Intensification of sub-daily rainfall extremes in CPMs and daily rainfall extremes in GCMs is also partly related to changes to future large-scale dynamics ${ }^{105,95,69}$. For example, the majority of 1 -h annual maximum precipitation across the western US are linked to two coherent mid-latitude synoptic patterns: disturbances propagating along the jet stream, and cutoff upper-level lows ${ }^{173}$. Atmospheric rivers also play a role in the generation of precipitation extremes at short and long durations ${ }^{174,175}$. However, other studies have shown that regional-scale circulation as viewed through the lens of weather types has a large influence on the frequency and intensity of rainfall extremes, but this influence tends to weaken for shorter-duration $(<6-12$ hours) extremes ${ }^{176}$. Thus, regional processes and their impact on dynamical responses will be crucial in determining how regional precipitation intensities respond to climate change and therefore their effect on flood hazard.

Changes in the large-scale environment, such as atmospheric stability, absolute and relative humidity and large-scale circulation, are non-uniform across the globe, depending on latitude but also on ocean/land. For instance, changes in stability over tropical oceans are close to moist adiabatic ${ }^{118}$, but the stabilization over the mid-latitudes can be partly compensated for by enhanced surface temperatures due to surface drying ${ }^{108}$.

\section{Implications for flood hazard}

It is not simple to relate changes in extreme rainfall to changes in floods which can be caused by a multitude of drivers ranging from long- and short-duration rainfall events, snowmelt, rain-on-snow events, and/or elevated storm tides ${ }^{177,178,179,180}$. For example, serious floods recorded across Europe and Asia have been linked to persistent atmospheric circulation patterns ${ }^{181,182,183}$. Floods triggered by sub-daily rainfall extremes 
can be classified either as 'short-rain' (several hours to a day) or 'flash' ( $<90 \mathrm{~min})$ floods ${ }^{179,48}$, with the latter being particularly hazardous ${ }^{184}$ due to their rapid onset and therefore the difficulty in providing early emergency warnings ${ }^{185,186}$. Small mountainous catchments and urban catchments are often highly sensitive to sub-daily rainfall extremes, with rainfall responsiveness driven by catchment size, terrain, vegetation and the degree of imperviousness and channelization ${ }^{8}$.

First-order approximations from flood theory suggest that both the volume and peak flow rate (and consequently the height, areal extent and momentum) of the flood could be expected to increase nonlinearly with increasing catchment-average extreme rainfall intensity. In the case of flood volume, as rainfall intensity increases, proportionally more rainfall can be expected to convert to the flood hydrograph ('excess rainfall') rather than be intercepted by vegetation or absorbed into the soils and other catchment storages $^{187,188}$. Furthermore, flood peaks often increase non-linearly with excess rainfall increase due to increasing velocities with increasing discharge ${ }^{189}$. However, the above expectation assumes stationarity of all other flood generation processes, which is unlikely to be true as the climate changes ${ }^{190}$. Other relevant factors that may also be subject to climatic changes include rainfall temporal patterns ${ }^{191,98}$, antecedent catchment conditions ${ }^{192,193,194}$, and interactions between sub-daily rainfall extremes and other processes such as snowmelt ${ }^{195}$ and storm surge ${ }^{196,197,198}$ as part of 'compound' flooding events ${ }^{199,200}$. Non-linear responses in flooding and its seasonality are also possible as climate evolves.

Due to the complexity and diversity of flood generation processes and direct human influence on catchment characteristics as summarized in Fig. 6, it is not possible to directly extrapolate the intensification of subdaily rainfall to changes to flood hazard, leading to a focus on empirical and process-based modelling evidence. Although on average globally more stations exhibit decreasing trends than increasing trends in daily discharge, this pattern was reversed for the smallest two catchment categories (areas less than $\left.390 \mathrm{~km}^{2}\right)^{201}$. This is consistent with (but not conclusive evidence for) the hypothesis that sub-daily rainfall intensification is translating into a commensurate intensification of short-rain and flash floods. Most regional studies of flood trends also focus on daily or longer timescales [for example, see Table $1^{201}$ for a summary of regional studies of flood trends], with very little published at the sub-daily timescale, except for one study exploring the atmospheric mechanisms that lead to flash floods ${ }^{202}$. A major challenge for empirical studies is the relative lack of streamflow data at sub-daily scales and/or for small catchments; for example, only $21 \%$ of the GSIM record ${ }^{203}$ - currently the largest record of historical streamflow globallyis for catchments below $100 \mathrm{~km}^{2}$. Furthermore, for urban catchments, it is particularly challenging to attribute changes in floods to rainfall intensification due to the significant urbanization that is likely to have occurred over the recording period ${ }^{204}$. These challenges limit the capacity to make definitive statements on whether intensification of sub-daily rainfall can be detected in streamflow records based on empirical data alone.

Modelling studies potentially represent an alternative line of evidence for changes to flooding due to subdaily rainfall. There are now a number of studies predicting changes in flood hazard and/or risk at the global scale using daily global hydrological model simulations ${ }^{205,206,207,208}$. However, these models have yet to be applied at sub-daily resolutions due to the absence of a reliable global atmospheric forcing dataset at the sub-daily timescale ${ }^{209}$, significant challenges in modelling the key hydrological processes, and calibration difficulties as space/time resolutions increase [see ${ }^{210,211}$ for reviews on state-of-the-art global hydrological modelling efforts]. In contrast, local-scale studies focusing on individual catchments suggest that sub-daily rainfall increases will translate to increased flood risk ${ }^{212,49,213}$, but these findings are difficult to generalize to the global scale.

\section{Summary and Future Perspectives}


Observations, modelling experiments and regional temperature scaling indicate an intensification of heavy rainfall extremes with warming at a rate consistent with the increase in atmospheric moisture (the thermodynamic Clausius-Clapeyron rate of approximately $7 \%$ per degree warming near to the surface). However, there is evidence from observed trends and temperature scaling of stronger increases in shortduration extreme rainfall intensities than expected from atmospheric moisture increases alone (super-CC changes). This suggests that sub-daily rainfall intensities may increase with warming at rates greater than CC. CPMs also indicate higher intensifications in short-duration extreme rainfall intensities for rarer events.

Idealized and full-scale CPM experiments have identified some mechanisms behind localized super-CC intensification of sub-daily precipitation extremes. This intensification is likely due to enhanced latent heat release, increasing buoyancy in convective clouds, increased updraft velocities and increases in moistureconvergence producing larger storms (see Fig. 5), which can also be observed as effects of the urban heat island in cities. Increases in atmospheric stability towards a dry adiabat in the mid-latitudes with warming are expected to dampen these increases, although in the tropics, the warming profile will be closer to moist adiabatic than constant. Moreover, changes to relative humidity affect rain intensity in various and uncertain ways by influencing the triggering of convection, cold pool dynamics, cloud entrainment and atmospheric stability. The important role of changes to large-scale atmospheric circulation dynamics is clear but not well-researched, with important potential control over static stability and CAPE. However, atmospheric dynamics are likely have a greater impact on longer-duration extreme rainfall intensities and frequencies than short-duration storms, although playing an important role in providing moisture to initialize and sustain intense convective systems.

Evidence is so far unclear whether storm size will increase with warming, with conflicting findings from different regions. Despite this, both observational and modelling studies indicate increases to the peak intensity of the storm with warming, although historical rainfall intensification is small so far compared to the projected intensification over the $21^{\text {st }}$ century. This increase in peak intensity coupled with an increasing storm footprint could compound to cause significant increases in total event rainfall in some regions, with a doubling of the heavy precipitation volume of future meso-scale convective systems by the end of the $21^{\text {st }}$ century in a high emission scenario study for the U.S. Evidence also suggests that large-scale convergence of moisture mostly affects the storm size or frequency but less so its intensity.

There is limited evidence of correspondence between the response of precipitation intensities to day-to-day climate variability and their response to warming. Therefore, the relevance of present day 'apparent' scaling to climate change is questionable. Understanding precipitation scaling with surface air temperature is hindered by confounding effects which can cause negative scaling: moisture limitations, influences of seasonality, mixing of rain types and weather regimes, as well as feedbacks from the storm itself. Scaling with dew point temperature, as a direct proxy for humidity, removes some local dynamical factors and produces more consistent sensitivities close to $\mathrm{CC}$, or above, which, in limited studies so far, show greater correspondence with climate scaling in CPM simulations. An important additional confounder is change to large-scale circulation, but for changes to short-duration precipitation intensities atmospheric state variables (like humidity) are likely more relevant. Therefore, dew point temperature scaling is likely more appropriate for interpreting change to short-duration extremes but care must still be exercised as large-scale circulation sets up the atmospheric state (stability, humidity and wind shear) in which convective systems develop. Finally, the atmospheric dry lapse rate change towards more stable conditions in the future climate could lead to smaller increases in sub-daily rainfall intensities than that derived from apparent scaling.

Hazardous flooding is likely susceptible to intensification of sub-daily extreme rainfall, particularly at short-time scales, but there is still limited quantitative evidence. Although most regional flood trend studies focus on daily or longer time scales, evidence is emerging that sub-daily rainfall intensification is related to an intensification of flash flooding, at least locally. This recent signal emergence may be expected since historical rainfall intensification is small compared to projected changes by the end of the 21 st century. 
Moving forward, flood hazard may be more dominated by rainfall change than seen in the historical record, but due to the complexity of the flood generation process direct extrapolation is not possible. Since shortduration extreme rainfall intensification is expected to increase flood hazard non-linearly, and urban heat island effects enhance this intensification further, global warming likely has serious implications for flash flooding in globally, and particularly in cities, and this requires urgent climate-change adaptation measures.

\section{Future Perspectives}

Huge advances have been made in understanding and predicting changes to sub-daily rainfall extremes. A coordinated data collection effort by the international community has led to the first global dataset of subdaily rainfall observations ${ }^{27}$, with over 25,000 stations available (some 16,000 with more than 10 years of data). Open-source code is available for quality control and sub-daily precipitation indices are being produced to complement the Expert Team on Climate Change Detection and Indices (ETCCDI) daily precipitation indices. The new quality-controlled GSDR dataset and sub-daily precipitation indices have great potential in improving existing merged datasets such as MSWEP ${ }^{214,215}$, radar-gauge datasets, and in evaluating satellite products and CPMs.

There have been corresponding large advances in CPM modelling. CPMs offer a promising avenue for investigating and explaining mechanisms as they can simulate sub-daily rainfall extremes more realistically compared to traditional climate models that rely on deep convection parameterizations. However, realistically simulating the change in sub-daily rainfall extremes depends on capturing multi-scale processes that span micro- to global scales. While some of these processes are better understood (for example, increase in atmospheric moisture and stability), others are highly uncertain (for example, changes in precipitation efficiency, cloud entrainment, cloud-aerosol interactions). Promising developments are the emergence of global CPMs (Stevens et al. 2019), the first ensemble of projections at convection-permitting scales ${ }^{88}$, and coordinated CPM intercomparison projects ${ }^{216}$, which will allow a spatiotemporal multi-scale assessment of precipitation extremes and an improved understanding of uncertainties in sub-daily extreme rainfall projections. It may also be advantageous to use CPMs to evaluate the relationship between apparent scaling and climate scaling spatially.

Although a large literature on temperature scaling exists, most studies use near-surface air temperature to derive the apparent scaling ${ }^{23,22}$. Growing consensus points to the importance of including moisture in the assessments ${ }^{60}$ as near-surface air temperature changes generally exceed dew point temperature changes, reflecting decreases in relative humidity with warming ${ }^{123}$. Scaling with dew point temperature, as a direct proxy for humidity, thereby reduces mismatch between temperature and humidity and its relation with atmospheric circulation. However, even an average daily dew point temperature may not be appropriate for scaling since changes in the diurnal timing of convection mean that the actual humidity (dew point temperature) increase at the time of the rainfall event is less than what would be expected based on the mean changes ${ }^{217}$. To be able to use scaling in a climate change context, careful analysis of the actual humidity increase for the environment of the clouds is still needed. Careful interpretation of present day scalings of extreme precipitation with warming must then be effectively combined with process understanding and detailed modelling to evaluate the likely responses under climate change.

Although much progress has been made, observational and model understanding of changes to sub-daily precipitation extremes must be further developed through a common framework. Global-scale analyses using consistent methodologies may provide a coherent picture of change in response to warming. Currently studies cannot be easily compared and differences may occur for physical reasons or from statistical/methodological incompatibilities. We recommend that a moisture component, such as dew point temperature, must be included in temperature-scaling studies, or other methods applied to remove meteorological factors that are related to local scale processes rather than climate change response. Global studies ${ }^{11}$ should be performed using common, robust and repeatable methods to examine apparent scaling 
at different durations and spatial scales. At the same time, we recommend coordinated PGW or full CPM experiments over the same domain(s), with the same forcing/perturbation, and at the same resolution to provide robust intermodel comparisons. This would establish whether there is a scale at which model projections start to converge to similar projections, particularly in relation to precipitation extremes. Another promising avenue of research is the exploitation of transient CPM simulations, for example ensemble CPM simulations for the full 100-year period from 1980-2080 have been carried out at the UK Met Office as part of the UK Climate Projections project ${ }^{88}$. These new simulations will help connect the analysis of present-day variability from observational studies with long-term climate change projections from models.

Links between changes to rainfall extremes and flooding are less well established, even at longer durations such as daily. Observed increases in the intensity of precipitation extremes have not led to the expected increases in flooding. To connect changes in short-duration rainfall extremes to flooding we recommend a continued focus on expanding observational datasets (particularly as they relate to sub-daily streamflow events but also the various drivers of sub-daily floods), and supporting model developments by including better forcing datasets at the sub-daily timescale (for example, a reliable global sub-daily precipitation product). This would require commensurate increases in space/time model resolution and consideration of the representation of runoff generation processes ${ }^{187}$ of large-scale hydrological models, recognizing that there are often complex scaling effects between the small-scale catchments most vulnerable to flash floods and the larger-scale basins that are often the focus of these modelling efforts. Additionally, since flash flood occurrence depends on intense rainfall rates at small spatial and temporal scales, the clustering of convection could play a major role in determining the likelihood of such floods. GCMs and even CPMs do not sufficiently resolve such clustering. Understanding how clouds organize non-randomly in space is a future challenge which could be tackled by improvements in CPM model resolution and increased theoretical understanding of cloud-interaction processes.

\section{Acknowledgements}

HJF, GL, RB, SB, SG, and EL were supported by the European Research Council (INTENSE; grant: ERC2013-CoG-617329). HJF and SB are also supported by FUTURE-STORMS (NE/R01079X/1). HJF is funded by the Wolfson Foundation and the Royal Society by the Royal Society Wolfson Research Merit Award (WM140025). NCAR is sponsored by the National Science Foundation (NSF). EJK is supported by the Met Office Hadley Centre Climate Programme funded by BEIS and Defra (GA01101). RPA acknowledges the ERA4CS INDECIS project funded by the European Union Grant 690462. JOH gratefully acknowledges funding by a grant from the VILLUM Foundation (Grant 13168) and the European Research Council (ERC) under the European Union's Horizon 2020 research and innovation program (Grant 771859).

\section{Author Contributions}

H.J.F. led the writing of the manuscript, the figure contributions and coordinated all contributions. G.L. led the section on temperature scaling and produced Fig. 2. A.P. led the convection-permitting modelling review and produced Fig. 5. S.W. led the section on flood hazard. E.L. produced Fig. 1. R.P.A. produced Fig. 6. S.B. produced Fig. 4 and the supporting information. P.B. and J.H. produced Fig. 3. All authors discussed the review paper and co-wrote the manuscript. 
Figures
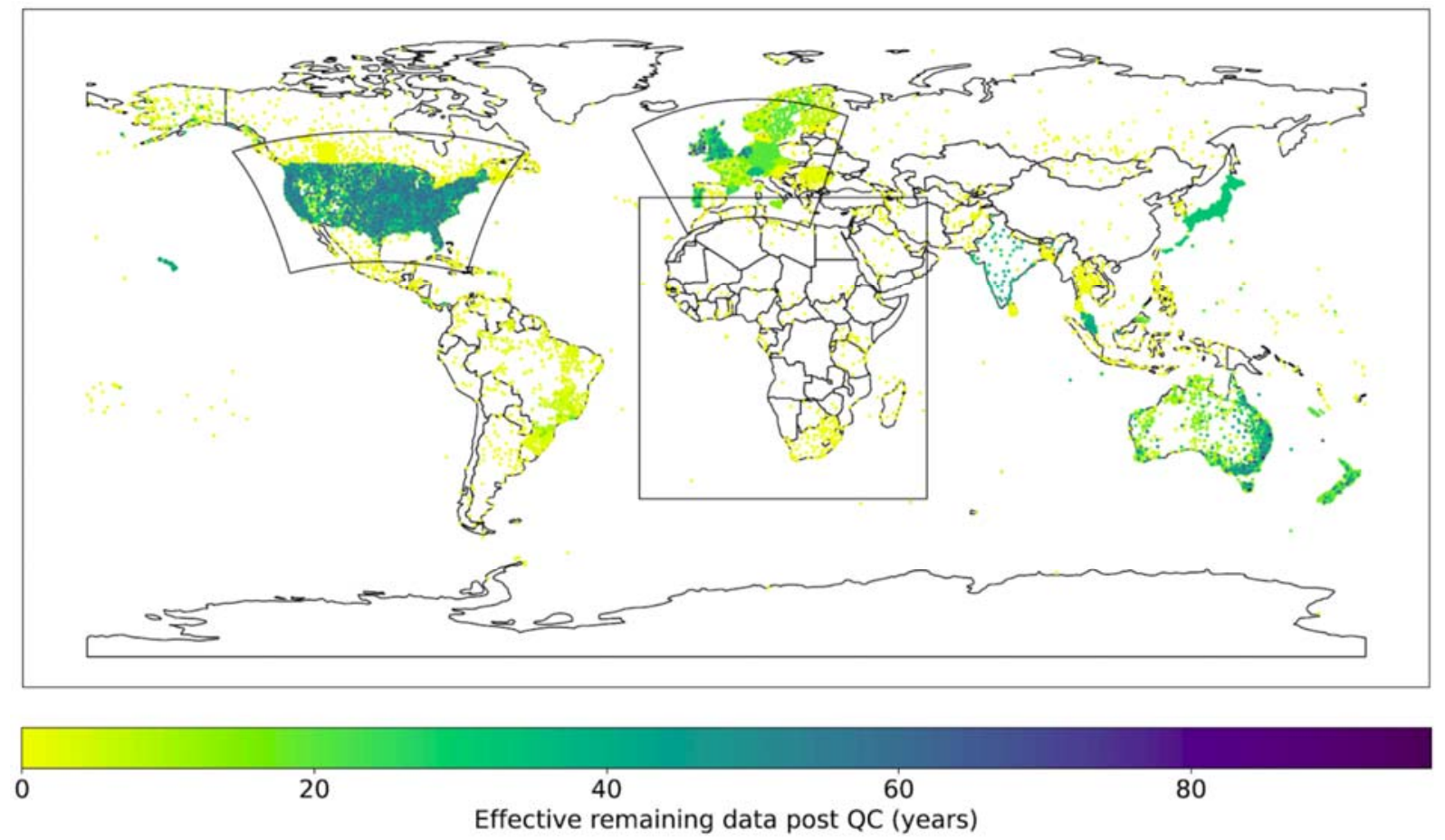

Figure 1: Hourly gauge record length remaining in the Global Sub-Daily Rainfall (GSDR) observed subdaily precipitation datase ${ }^{27}$ after quality-control (colored dots indicate gauge locations and record length) overlain by current continental-scale convection-permitting model (CPM) domains (enclosed by black lines). 

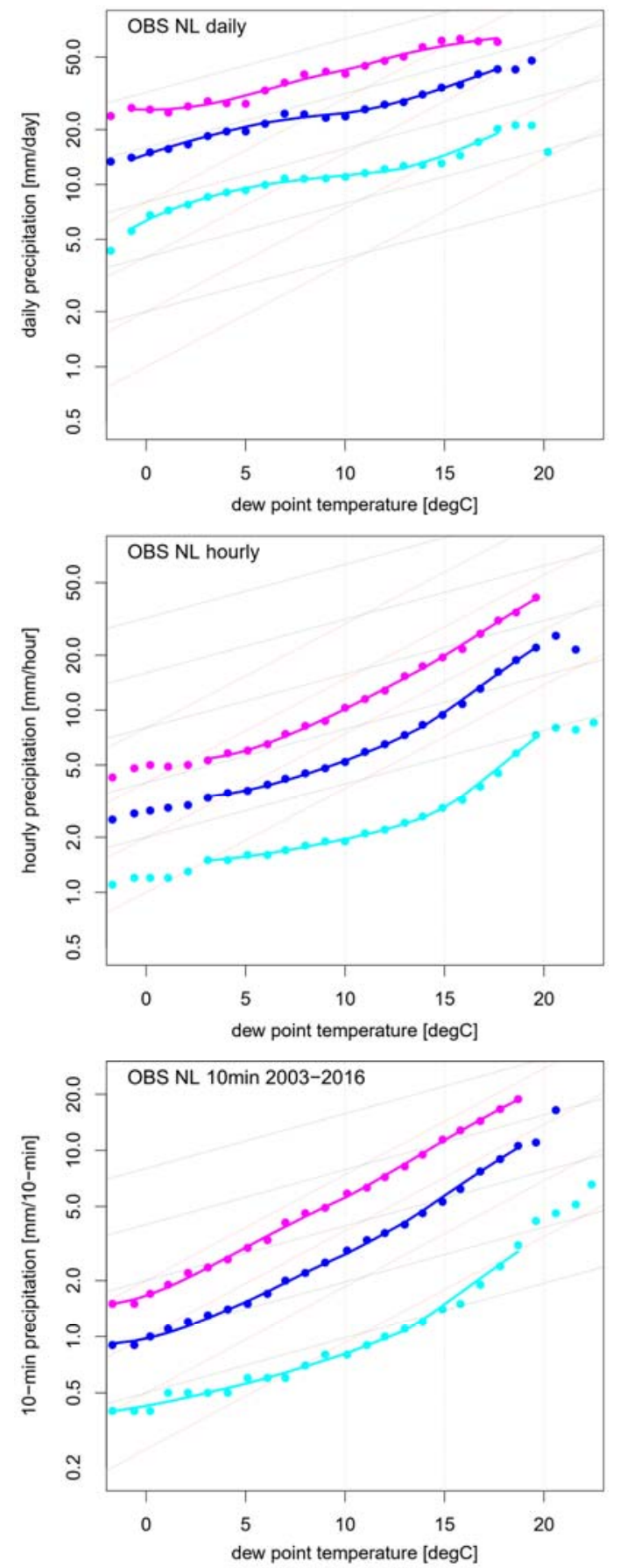

Figure 2: Scaling of rainfall intensities on dew point temperature data at (a) daily, (b) hourly, and (c) 10min resolution for the Netherlands, showing the 99.9 (magenta), 99 (blue), and 90th percentile (cyan). Dotted straight lines indicate the $\mathrm{CC}$ rate (black) and $2 \mathrm{CC}$ rate (red). The figures from top to bottom show the gradual change in scaling rates from the $\mathrm{CC}$ rate for daily precipitation to two times the $\mathrm{CC}$ rate for 10-min rainfall extremes. Note that for 10-min precipitation a very regular behavior is obtained for the highest percentile over a 20-degree dew point temperature range 

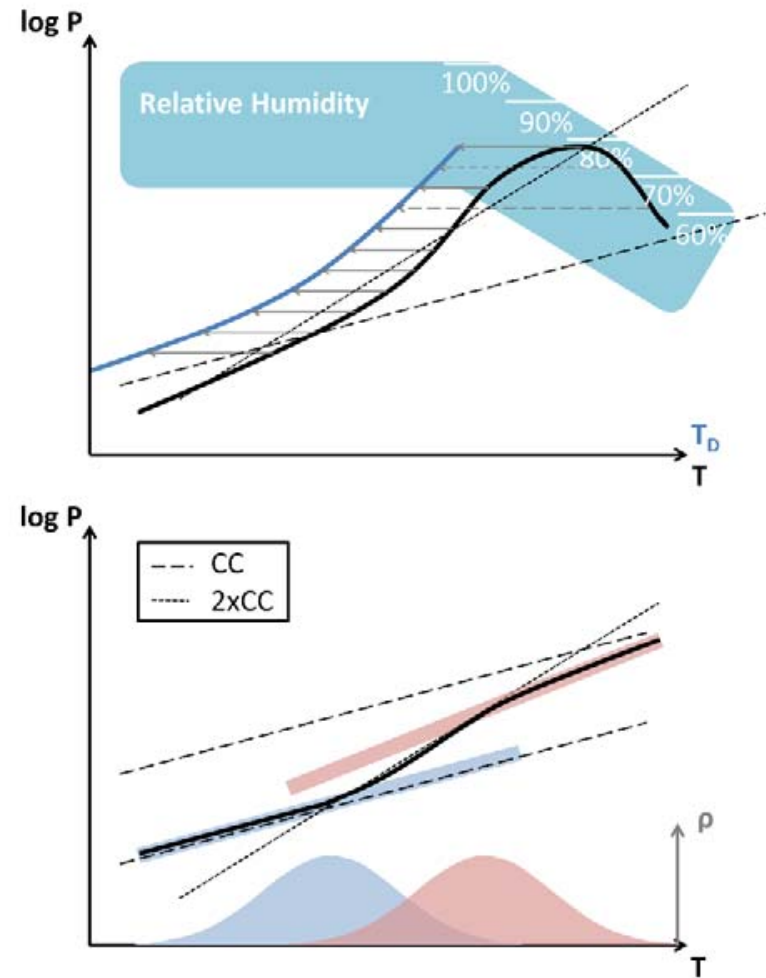

Figure 3: Schematic explaining the influence of accounting for humidity effects and rain types on the scaling of high percentile extreme rainfall. (a) Using dew point temperature (blue curve) instead of dry bulb (near surface) air temperature (black). When relative humidity is declining at higher temperatures, the dew point temperature is decreased more, indicated by (gray solid and dashed) arrows, such that the "hook shape" is reduced or disappears. (b) Considering large-scale stratiform precipitation (light blue) distributed across a lower temperature range, and convective precipitation (pink) across a higher temperature range, and different intensity and scaling (CC and super-CC, respectively) of each type. PDFs of the occurrence are shown as shaded surfaces for stratiform (light blue) and convective (pink) rainfall types. The combined scaling becomes much steeper in the transition between the two distributions, as indicated by the black curve. 


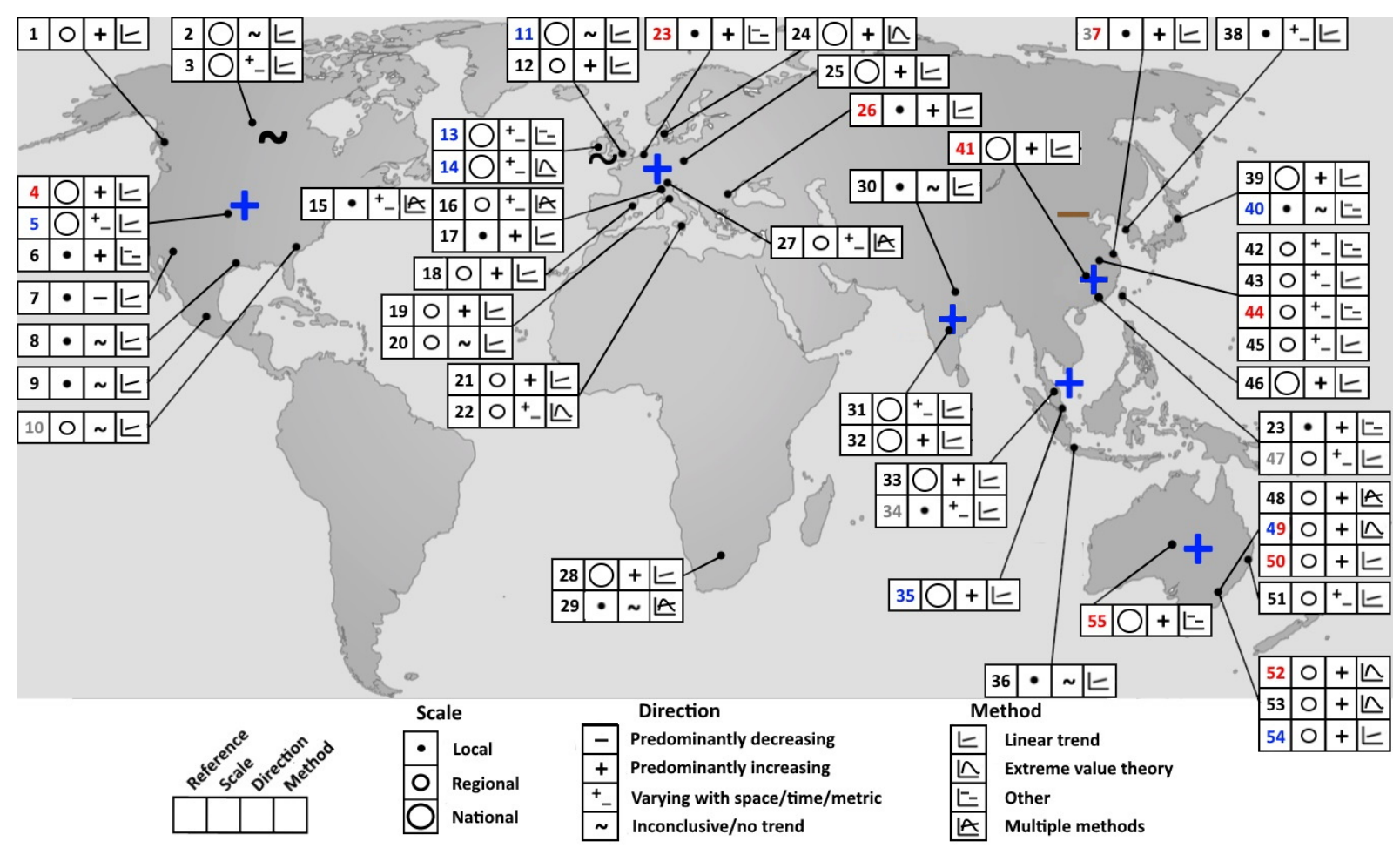

Figure 4: Summary of existing knowledge of observed changes in the frequency and/or intensity of subdaily rainfall extremes. Information provided shows the spatial scale of each study, predominant direction of change, and methodology used. The direction of change includes analyses of different seasons, periods of analysis, and metrics of extremes. The large symbols on the map indicate areas where a predominant direction of change is evident from a national-scale study or a majority of regional studies. The reference indices correspond to the citations provided in Table S1 and associated references in the Supporting Information. These are color coded here to indicate if results are analyzed in the context of various drivers: temperature or temperature (CC) scaling (red), large-scale circulation (blue), or urbanization (grey). 


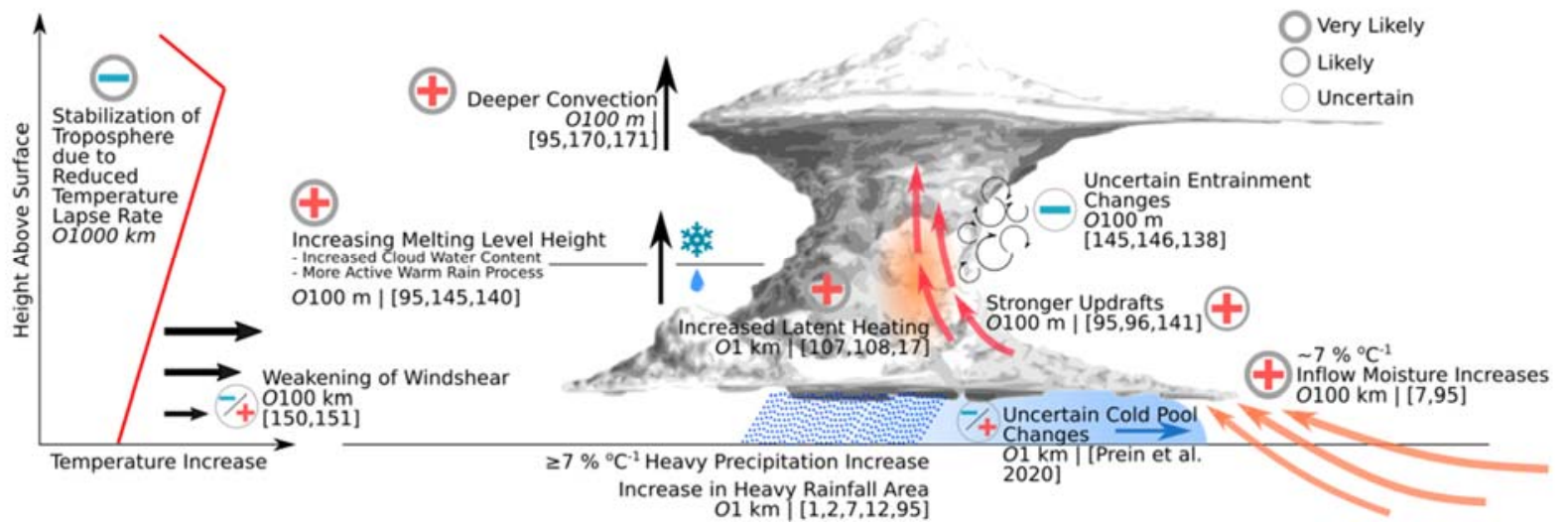

Figure 5: Climate change induced changes in extreme convective sub-daily precipitation processes. Plus/minus symbols indicate a positive/negative feedback regarding extreme precipitation intensity. The order of the characteristic spatial scale $(\mathrm{O})$ is provided for each process and numbers in brackets indicate key references for each change. Uncertainties are indicated as the line thickness of circles around the feedback symbols with thin lines showing uncertain changes (little consensus, lack of research, missing first-order principle understanding), likely changes (some consensus, increasing amount of literature, based on first-order principles), and very likely changes (consensus established, changes have been detected in observational records) 


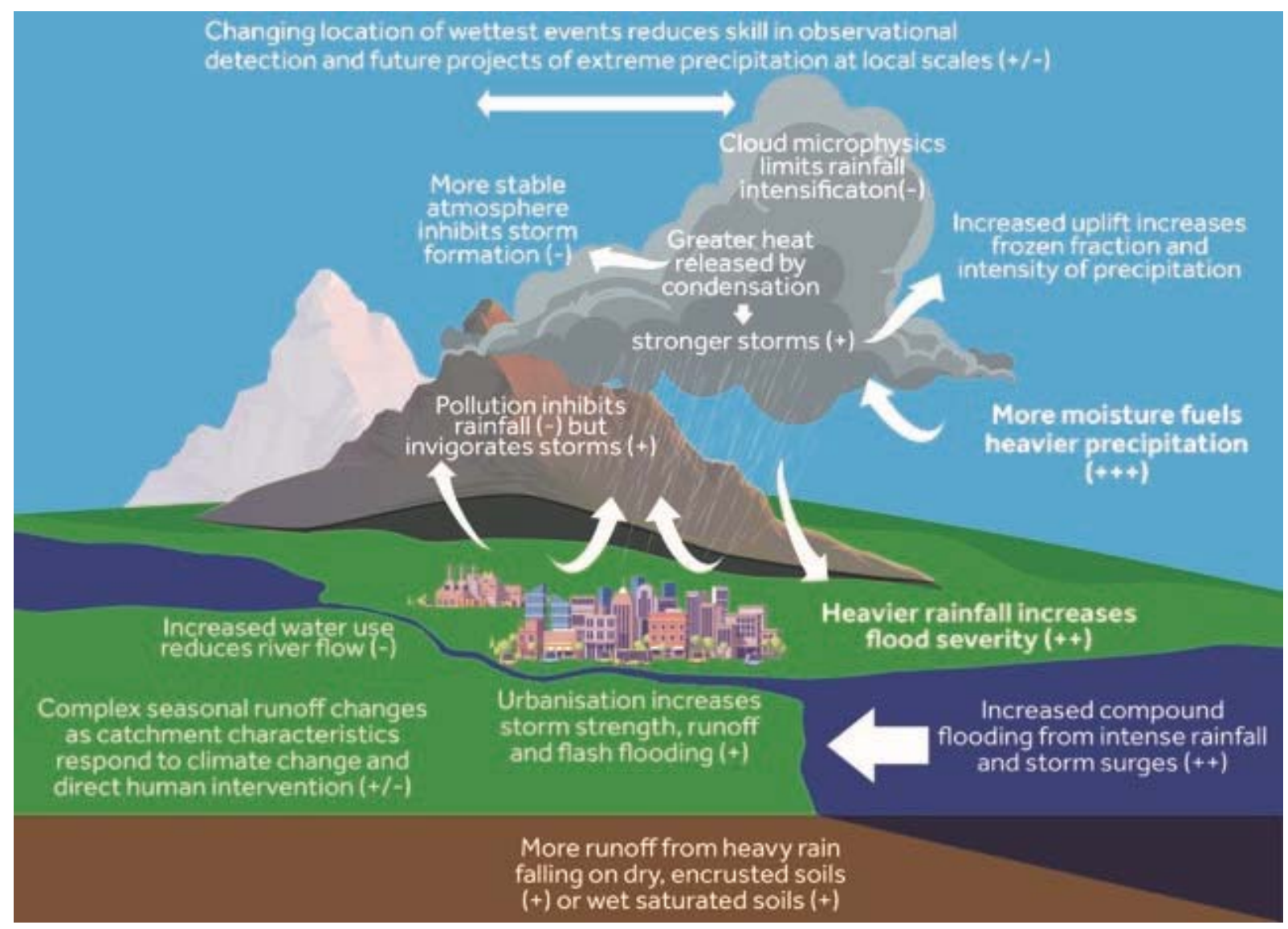

Figure 6: Schematic illustrating factors important in determining changes in sub-daily extreme precipitation and flooding (adapted from Figure 5 in 218 to include processes specific to sub-daily precipitation extremes, with contributions to increases $(+)$ and decreases $(-)$ marked).

\section{References}

1. Guerreiro, S. B. et al. Detection of continental-scale intensification of hourly rainfall extremes. Nat. Clim. Chang. 8, (2018).

2. Fischer, E. M. \& Knutti, R. Observed heavy precipitation increase confirms theory and early models. Nature Climate Change vol. 6 986-991 (2016).

3. Westra, S., Alexander, L. V. \& Zwiers, F. W. Global increasing trends in annual maximum daily precipitation. J. Clim. 26, 3904-3918 (2013).

4. Neelin, J. D., Sahany, S., Stechmann, S. N. \& Bernstein, D. N. Global warming precipitation accumulation increases above the current-climate cutoff scale. Proc. Natl. Acad. Sci. 114, 1258 1263 (2017).

5. O'Gorman, P. A. \& Muller, C. J. How closely do changes in surface and column water vapor follow Clausius-Clapeyron scaling in climate change simulations? Environ. Res. Lett. 5, (2010).

6. Schneider, T., O'Gorman, P. A. \& Levine, X. J. WATER VAPOR AND THE DYNAMICS OF CLIMATE CHANGES. Rev. Geophys. 48, RG3001 (2010).

7. Trenberth, K. E., Dai, A., Rasmussen, R. M. \& Parsons, D. B. The changing character of precipitation. Bulletin of the American Meteorological Society vol. 84 1205-1217+1161 (2003).

8. Westra, S. et al. Future changes to the intensity and frequency of short-duration extreme rainfall. 
Reviews of Geophysics vol. 52 522-555 (2014).

9. Scherrer, S. C. et al. Emerging trends in heavy precipitation and hot temperature extremes in Switzerland. J. Geophys. Res. Atmos. 121, 2626-2637 (2016).

10. Rajczak, J. \& Schär, C. Projections of Future Precipitation Extremes Over Europe: A Multimodel Assessment of Climate Simulations. J. Geophys. Res. Atmos. 122, 10,773-10,800 (2017).

11. Ali, H., Fowler, H. J. \& Mishra, V. Global Observational Evidence of Strong Linkage Between Dew Point Temperature and Precipitation Extremes. Geophys. Res. Lett. 45, (2018).

12. Lenderink, G. \& Van Meijgaard, E. Linking increases in hourly precipitation extremes to atmospheric temperature and moisture changes. Environ. Res. Lett. 5, (2010).

13. Lenderink, G., Mok, H. Y., Lee, T. C. \& Van Oldenborgh, G. J. Scaling and trends of hourly precipitation extremes in two different climate zones - Hong Kong and the Netherlands. Hydrol. Earth Syst. Sci. 15, 3033-3041 (2011).

14. Panthou, G., Mailhot, A., Laurence, E. \& Talbot, G. Relationship between surface temperature and extreme rainfalls: A multi-time-scale and event-based analysis. J. Hydrometeorol. 15, 1999-2011 (2014).

15. Berg, P., Moseley, C. \& Haerter, J. O. Strong increase in convective precipitation in response to higher temperatures. Nat. Geosci. 6, 181-185 (2013).

16. Park, I. H. \& Min, S. K. Role of convective precipitation in the relationship between subdaily extreme precipitation and temperature. J. Clim. 30, 9527-9537 (2017).

17. Loriaux, J. M., Lenderink, G., De Roode, S. R. \& Siebesma, A. P. Understanding convective extreme precipitation scaling using observations and an entraining plume model. J. Atmos. Sci. 70, 3641-3655 (2013).

18. Lenderink, G., Barbero, R., Loriaux, J. M. \& Fowler, H. J. Super-Clausius-Clapeyron scaling of extreme hourly convective precipitation and its relation to large-scale atmospheric conditions. $J$. Clim. 30, 6037-6052 (2017).

19. Haerter, J. O. \& Schlemmer, L. Intensified Cold Pool Dynamics Under Stronger Surface Heating. Geophys. Res. Lett. (2018) doi:10.1029/2017GL076874.

20. Nie, J., Sobel, A. H., Shaevitz, D. A. \& Wang, S. Dynamic amplification of extreme precipitation sensitivity. Proc. Natl. Acad. Sci. U. S. A. 115, 9467-9472 (2018).

21. Kendon, E. J. et al. Heavier summer downpours with climate change revealed by weather forecast resolution model. Nat. Clim. Chang. 4, (2014).

22. Ban, N., Schmidli, J. \& Schär, C. Heavy precipitation in a changing climate: Does short-term summer precipitation increase faster? Geophys. Res. Lett. 42, 1165-1172 (2015).

23. Prein, A. F. et al. The future intensification of hourly precipitation extremes. Nat. Clim. Chang. 7, 48-52 (2017).

24. Kendon, E. J. et al. Enhanced future changes in wet and dry extremes over Africa at convectionpermitting scale. Nat. Commun. 10, 1794 (2019).

25. Formayer, H. \& Fritz, A. Temperature dependency of hourly precipitation intensities - surface versus cloud layer temperature. Int. J. Climatol. 37, 1-10 (2017).

26. Blenkinsop, S. et al. The INTENSE project: using observations and models to understand the past, present and future of sub-daily rainfall extremes. Adv. Sci. Res. 15, 117-126 (2018).

27. Lewis, E. et al. GSDR: A global sub-daily rainfall dataset. J. Clim. 32, (2019).

28. Barbero, R. et al. A synthesis of hourly and daily precipitation extremes in different climatic regions. Weather Clim. Extrem. (2019) doi:10.1016/j.wace.2019.100219.

29. Li, X. F. et al. Global distribution of the intensity and frequency of hourly precipitation and their responses to ENSO. Clim. Dyn. 54, 4823-4839 (2020).

30. Lochbihler, K., Lenderink, G. \& Siebesma, A. P. The spatial extent of rainfall events and its relation to precipitation scaling. Geophys. Res. Lett. 44, 8629-8636 (2017).

31. Ban, N., Schmidli, J. \& Schär, C. Evaluation of the convection-resolving regional climate modeling approach in decade-long simulations. J. Geophys. Res. 119, 7889-7907 (2014).

32. Chan, S. C., Kendon, E. J., Roberts, N. M., Fowler, H. J. \& Blenkinsop, S. The characteristics of 
summer sub-hourly rainfall over the southern UK in a high-resolution convective permitting model. Environ. Res. Lett. 11, (2016).

33. Liu, C. et al. Continental-scale convection-permitting modeling of the current and future climate of North America. Clim. Dyn. 49, 71-95 (2017).

34. Kendon, E. J., Roberts, N. M., Senior, C. A. \& Roberts, M. J. Realism of rainfall in a very highresolution regional climate model. J. Clim. 25, 5791-5806 (2012).

35. Prein, A. F. et al. Added value of convection permitting seasonal simulations. Clim. Dyn. 41, 2655-2677 (2013).

36. Gentry, M. S. \& Lackmann, G. M. Sensitivity of Simulated Tropical Cyclone Structure and Intensity to Horizontal Resolution. Mon. Weather Rev. 138, 688-704 (2010).

37. Colle, B. A., Mass, C. F., Colle, B. A. \& Mass, C. F. The 5-9 February 1996 Flooding Event over the Pacific Northwest: Sensitivity Studies and Evaluation of the MM5 Precipitation Forecasts. http://dx.doi.org/10.1175/1520-0493(2000)128<0593:TFFEOT>2.0.CO;2 (2000) doi:10.1175/1520-0493(2000)128<0593:TFFEOT $>2.0 . C O ; 2$.

38. Colle, B. A., Garvert, M. F., Wolfe, J. B., Mass, C. F. \& Woods, C. P. The 13-14 December 2001 IMPROVE-2 event. Part III: Simulated microphysical budgets and sensitivity studies. J. Atmos. Sci. 62, 3535-3558 (2005).

39. Bartsotas, N. S., Nikolopoulos, E. I., Anagnostou, E. N., Solomos, S. \& Kallos, G. Moving toward Subkilometer Modeling Grid Spacings: Impacts on Atmospheric and Hydrological Simulations of Extreme Flash Flood-Inducing Storms. J. Hydrometeorol. 18, 209-226 (2017).

40. Chan, S. C., Kendon, E. J., Roberts, N. M., Fowler, H. J. \& Blenkinsop, S. Downturn in scaling of UK extreme rainfall with temperature for future hottest days. Nat. Geosci. 9, 24-28 (2016).

41. Schär, C., Frei, C., Lüthi, D. \& Davies, H. C. Surrogate climate-change scenarios for regional climate models. Geophys. Res. Lett. 23, 669-672 (1996).

42. Kawase, H. et al. Intermodel variability of future changes in the Baiu rainband estimated by the pseudo global warming downscaling method. J. Geophys. Res. Atmos. 114, (2009).

43. Rasmussen, R. et al. High-resolution coupled climate runoff simulations of seasonal snowfall over Colorado: A process study of current and warmer climate. J. Clim. 24, 3015-3048 (2011).

44. Brogli, R., Kröner, N., Sørland, S. L., Lüthi, D. \& Schär, C. The Role of Hadley Circulation and Lapse-Rate Changes for the Future European Summer Climate. J. Clim. 32, 385-404 (2019).

45. Hentgen, L., Ban, N., Kröner, N., Leutwyler, D. \& Schär, C. Clouds in Convection-Resolving Climate Simulations Over Europe. J. Geophys. Res. Atmos. 124, 3849-3870 (2019).

46. Mahoney, K., Alexander, M. A., Thompson, G., Barsugli, J. J. \& Scott, J. D. Changes in hail and flood risk in high-resolution simulations over Colorado's mountains. Nat. Clim. Chang. 2, 125131 (2012).

47. Wasko, C. \& Sharma, A. Steeper temporal distribution of rain intensity at higher temperatures within Australian storms. Nat. Geosci. 8, 527-529 (2015).

48. Archer, D. R. \& Fowler, H. J. Characterising flash flood response to intense rainfall and impacts using historical information and gauged data in Britain. J. Flood Risk Manag. 11, (2018).

49. Fadhel, S., Rico-Ramirez, M. A. \& Han, D. Sensitivity of peak flow to the change of rainfall temporal pattern due to warmer climate. J. Hydrol. 560, 546-559 (2018).

50. Arnbjerg-Nielsen, K. et al. Impacts of climate change on rainfall extremes and urban drainage systems: A review. Water Science and Technology vol. 68 16-28 (2013).

51. Bao, J., Sherwood, S. C., Alexander, L. V. \& Evans, J. P. Future increases in extreme precipitation exceed observed scaling rates. Nat. Clim. Chang. 7, 128-132 (2017).

52. Lenderink, G. \& Van Meijgaard, E. Increase in hourly precipitation extremes beyond expectations from temperature changes. Nat. Geosci. 1, 511-514 (2008).

53. Hardwick Jones, R., Westra, S. \& Sharma, A. Observed relationships between extreme sub-daily precipitation, surface temperature, and relative humidity. Geophys. Res. Lett. 37, (2010).

54. Wasko, C. \& Sharma, A. Quantile regression for investigating scaling of extreme precipitation with temperature. Water Resour. Res. 50, 3608-3614 (2014). 
55. Schär, C. et al. Percentile indices for assessing changes in heavy precipitation events. Clim. Change 137, 201-216 (2016).

56. Wang, G. et al. The peak structure and future changes of the relationships between extreme precipitation and temperature. Nat. Clim. Chang. 7, 268-274 (2017).

57. Drobinski, P. et al. Scaling precipitation extremes with temperature in the Mediterranean: past climate assessment and projection in anthropogenic scenarios. Clim. Dyn. 51, 1237-1257 (2018).

58. Maeda, E. E., Utsumi, N. \& Oki, T. Decreasing precipitation extremes at higher temperatures in tropical regions. Nat. Hazards 64, 935-941 (2012).

59. Barbero, R., Westra, S., Lenderink, G. \& Fowler, H. J. Temperature-extreme precipitation scaling: a two-way causality? Int. J. Climatol. 38, e1274-e1279 (2018).

60. Lenderink, G., Barbero, R., Westra, S. \& Fowler, H. J. Reply to comments on "Temperatureextreme precipitation scaling: a two-way causality?” Int. J. Climatol. 38, (2018).

61. Trenberth, K. E. \& Shea, D. J. Relationships between precipitation and surface temperature. Geophys. Res. Lett. 32, 1-4 (2005).

62. Wasko, C., Lu, W. T. \& Mehrotra, R. Relationship of extreme precipitation, dry-bulb temperature, and dew point temperature across Australia. Environ. Res. Lett. 13, (2018).

63. Zhang, W., Villarini, G. \& Wehner, M. Contrasting the responses of extreme precipitation to changes in surface air and dew point temperatures. Clim. Change (2019) doi:10.1007/s10584-01902415-8.

64. Zhang, X., Zwiers, F. W., Li, G., Wan, H. \& Cannon, A. J. Complexity in estimating past and future extreme short-duration rainfall. Nat. Geosci. 10, 255-259 (2017).

65. Haerter, J. O. \& Berg, P. Unexpected rise in extreme precipitation caused by a shift in rain type? Nature Geoscience vol. 2 372-373 (2009).

66. Berg, P. et al. Seasonal characteristics of the relationship between daily precipitation intensity and surface temperature. J. Geophys. Res. Atmos. 114, (2009).

67. Bao, J., Sherwood, S. C., Alexander, L. V. \& Evans, J. P. Comments on "temperature-extreme precipitation scaling: A two-way causality?” Int. J. Climatol. 38, 4661-4663 (2018).

68. Lenderink, G. et al. Systematic increases in the thermodynamic response of hourly precipitation extremes in an idealized warming experiment with a convection-permitting climate model. Environ. Res. Lett. 14, (2019).

69. Pfahl, S., O'Gorman, P. A. \& Fischer, E. M. Understanding the regional pattern of projected future changes in extreme precipitation. Nat. Clim. Chang. 7, 423-427 (2017).

70. Li, Z. \& O'Gorman, P. A. Response of Vertical Velocities in Extratropical Precipitation Extremes to Climate Change. J. Clim. 33, 7125-7139 (2020).

71. Xiao, C., Wu, P., Zhang, L. \& Song, L. Robust increase in extreme summer rainfall intensity during the past four decades observed in China. Sci. Rep. 6, 1-9 (2016).

72. Syafrina, A. H., Zalina, M. D. \& Juneng, L. Historical trend of hourly extreme rainfall in Peninsular Malaysia. Theor. Appl. Climatol. 120, 259-285 (2015).

73. Arnone, E., Pumo, D., Viola, F., Noto, L. V. \& La Loggia, G. Rainfall statistics changes in Sicily. Hydrol. Earth Syst. Sci. 17, 2449-2458 (2013).

74. Madsen, H., Arnbjerg-Nielsen, K. \& Mikkelsen, P. S. Update of regional intensity-durationfrequency curves in Denmark: Tendency towards increased storm intensities. Atmos. Res. 92, 343349 (2009).

75. Barbero, R., Fowler, H. J., Lenderink, G. \& Blenkinsop, S. Is the intensification of precipitation extremes with global warming better detected at hourly than daily resolutions? Geophys. Res. Lett. 44, 974-983 (2017).

76. STATE OF THE CLIMATE IN 2018. doi:10.1175/2019BAMSStateoftheClimate.1.

77. Jun, C., Qin, X., Tung, Y. K. \& De Michele, C. On the statistical analysis of rainstorm events between historical (1777-1907) and modern (1961-2010) periods in Seoul, Korea. Int. J. Climatol. 40, 2078-2090 (2019).

78. Kendon, E. J., Blenkinsop, S. \& Fowler, H. J. When will we detect changes in short-duration 
precipitation extremes? J. Clim. 31, (2018).

79. Guerreiro, S. B., Kilsby, C. G. \& Serinaldi, F. Analysis of time variation of rainfall in transnational basins in Iberia: Abrupt changes or trends? Int. J. Climatol. 34, 114-133 (2014).

80. Serinaldi, F., Kilsby, C. G. \& Lombardo, F. Untenable nonstationarity: An assessment of the fitness for purpose of trend tests in hydrology. Adv. Water Resour. 111, 132-155 (2018).

81. Zhao, A. D., Stevenson, D. S. \& Bollasina, M. A. The role of anthropogenic aerosols in future precipitation extremes over the Asian Monsoon Region. Clim. Dyn. 52, 6257-6278 (2019).

82. Wu, M., Luo, Y., Chen, F. \& Wong, W. K. Observed Link of Extreme Hourly Precipitation Changes to Urbanization over Coastal South China. J. Appl. Meteorol. Climatol. 58, 1799-1819 (2019).

83. Burdanowitz, J., Buehler, S. A., Bakan, S. \& Klepp, C. The sensitivity of oceanic precipitation to sea surface temperature. Atmos. Chem. Phys. 19, 9241-9252 (2019).

84. Zhou, Y., Luo, M. \& Leung, Y. On the detection of precipitation dependence on temperature. Geophys. Res. Lett. 43, 4555-4565 (2016).

85. Shastri, H., Paul, S., Ghosh, S. \& Karmakar, S. Impacts of urbanization on Indian summer monsoon rainfall extremes. J. Geophys. Res. 120, 495-516 (2015).

86. Lin, C.-Y. \& Chen, W.-C. Impact of the Urban Heat Island Effect on Precipitation over a Complex Geographic Environment in Northern Taiwan PAO-LIANG CHANG. doi:10.1175/2010JAMC2504.1.

87. Han, J. Y., Baik, J. J. \& Lee, H. Urban impacts on precipitation. Asia-Pacific Journal of Atmospheric Sciences vol. 50 17-30 (2014).

88. Fosser, G. et al. UKCP Convection-permitting model projections: Science report. www.metoffice.gov.ukwww.metoffice.gov.uk (2019).

89. Saeed, S. et al. Multidecadal convection permitting climate simulations over Belgium: sensitivity of future precipitation extremes. Atmos. Sci. Lett. 18, 29-36 (2017).

90. Ban, N., Rajczak, J., Schmidli, J. \& Schär, C. Analysis of Alpine precipitation extremes using generalized extreme value theory in convection-resolving climate simulations. Clim. Dyn. 1-15 (2018) doi:10.1007/s00382-018-4339-4.

91. Gutmann, E. D. et al. Changes in hurricanes from a 13-Yr convection-permitting pseudo- global warming simulation. J. Clim. 31, 3643-3657 (2018).

92. Helsen, S. et al. Consistent scale-dependency of future increases in hourly extreme precipitation in two convection-permitting climate models. Clim. Dyn. 54, 1267-1280 (2020).

93. Hodnebrog, Ø. et al. Intensification of summer precipitation with shorter time-scales in Europe. Environ. Res. Lett. 14, 124050 (2019).

94. Dai, A., Rasmussen, R. M., Liu, C., Ikeda, K. \& Prein, A. F. A new mechanism for warm-season precipitation response to global warming based on convection-permitting simulations. Clim. Dyn. 1-26 (2017) doi:10.1007/s00382-017-3787-6.

95. Prein, A. F. et al. Increased rainfall volume from future convective storms in the US. Nat. Clim. Chang. 7, 880-884 (2017).

96. Rasmussen, K. L., Prein, A. F., Rasmussen, R. M., Ikeda, K. \& Liu, C. Changes in the convective population and thermodynamic environments in convection-permitting regional climate simulations over the United States. Clim. Dyn. 1-26 (2017) doi:10.1007/s00382-017-4000-7.

97. Allan, R. P. et al. Physically Consistent Responses of the Global Atmospheric Hydrological Cycle in Models and Observations. Surv. Geophys. 35, 533-552 (2014).

98. Wasko, C., Sharma, A. \& Johnson, F. Does storm duration modulate the extreme precipitationtemperature scaling relationship? Geophys. Res. Lett. 42, 8783-8790 (2015).

99. Risser, M. D. \& Wehner, M. F. Attributable Human-Induced Changes in the Likelihood and Magnitude of the Observed Extreme Precipitation during Hurricane Harvey. Geophys. Res. Lett. 44, 12,457-12,464 (2017).

100. Kanada, S. et al. A multimodel intercomparison of an intense typhoon in future, warmer climates by Four 5-km-Mesh models. J. Clim. 30, 6017-6036 (2017). 
101. Patricola, C. M. \& Wehner, M. F. Anthropogenic influences on major tropical cyclone events. Nature 563, 339-346 (2018).

102. Wang, S.-Y. S., Zhao, L., Yoon, J.-H., Klotzbach, P. \& Gillies, R. R. Quantitative attribution of climate effects on Hurricane Harvey's extreme rainfall in Texas. Environ. Res. Lett. 13, 054014 (2018).

103. van Oldenborgh, G. J. et al. Attribution of extreme rainfall from Hurricane Harvey, August 2017. Environ. Res. Lett. 12, 124009 (2017).

104. Prein, A. F. et al. Simulating North American mesoscale convective systems with a convectionpermitting climate model. Clim. Dyn. 1-16 (2017) doi:10.1007/s00382-017-3993-2.

105. Lackmann, G. M. The south-central U.S. flood of may 2010: Present and future. J. Clim. 26, 4688-4709 (2013).

106. Schumacher, R. S. \& Rasmussen, K. L. The formation, character and changing nature of mesoscale convective systems. Nat. Rev. Earth Environ. 1, 300-314 (2020).

107. Singleton, A. \& Toumi, R. Super-Clausius-Clapeyron scaling of rainfall in a model squall line. $Q$. J. R. Meteorol. Soc. 139, 334-339 (2013).

108. Attema, J. J., Loriaux, J. M. \& Lenderink, G. Extreme precipitation response to climate perturbations in an atmospheric mesoscale model. Environ. Res. Lett. 9, 014003 (2014).

109. Kendon, E. J. et al. Do convection-permitting regional climate models improve projections of future precipitation change? Bull. Am. Meteorol. Soc. 98, 79-93 (2017).

110. Chan, S. C. et al. Europe-wide precipitation projections at convection permitting scale with the Unified Model. Clim. Dyn. 1, 3 (2020).

111. Wasko, C., Sharma, A. \& Westra, S. Reduced spatial extent of extreme storms at higher temperatures. Geophys. Res. Lett. 43, 4026-4032 (2016).

112. Haerter, J. O., Berg, P. \& Hagemann, S. Heavy rain intensity distributions on varying time scales and at different temperatures. J. Geophys. Res. Atmos. 115, (2010).

113. Feng, Z. et al. Structure and Evolution of Mesoscale Convective Systems: Sensitivity to Cloud Microphysics in Convection-Permitting Simulations Over the United States. J. Adv. Model. Earth Syst. 10, 1470-1494 (2018).

114. Schumacher, R. S. \& Johnson, R. H. Characteristics of U.S. Extreme Rain Events during 19992003. (2006).

115. Haerter, J. O., Meyer, B. \& Boye Nissen, S. Diurnal self-aggregation. npj Clim. Atmos. Sci. 2020 31 3, 1-11 (2020).

116. Trenberth, K. E. Changes in precipitation with climate change. Clim. Res. 47, 123-138 (2011).

117. Lenderink, G. \& Van Meijgaard, E. Unexpected rise in extreme precipitation caused by a shift in rain type? Nature Geoscience vol. 2373 (2009).

118. Frierson, D. M. W. Robust increases in midlatitude static stability in simulations of global warming. Geophys. Res. Lett. 33, (2006).

119. Muller, C., O'Gorman, P. \& Back, L. Intensification of precipitation extremes with warming in a cloud-resolving model. J Clim 24, 2784-2800.

120. Keller, M. et al. The sensitivity of Alpine summer convection to surrogate climate change: an intercomparison between convection-parameterizing and convection-resolving models. Atmos. Chem. Phys. 18, 5253-5264 (2018).

121. Pendergrass, A. G. What precipitation is extreme? Science (80-. ). 360, 1072 LP - 1073 (2018).

122. Chan, S. C., Kendon, E. J., Roberts, N., Blenkinsop, S. \& Fowler, H. J. Large-scale predictors for extreme hourly precipitation events in convection-permitting climate simulations. J. Clim. 31, 2115-2131 (2018).

123. Lenderink, G. \& Attema, J. A simple scaling approach to produce climate scenarios of local precipitation extremes for the Netherlands. Environ. Res. Lett. 10, (2015).

124. Lepore, C., Veneziano, D. \& Molini, A. Temperature and CAPE dependence of rainfall extremes in the eastern United States. Geophys. Res. Lett. 42, 74-83 (2015).

125. Diffenbaugh, N. S., Scherer, M. \& Trapp, R. J. Robust increases in severe thunderstorm 
environments in response to greenhouse forcing. Proc. Natl. Acad. Sci. U. S. A. 110, 16361-16366 (2013).

126. Singh, M. S. \& O'Gorman, P. A. Influence of entrainment on the thermal stratification in simulations of radiative-convective equilibrium. Geophys. Res. Lett. 40, 4398-4403 (2013).

127. Romps, D. M. Clausius-clapeyron scaling of CAPE from analytical solutions to RCE. J. Atmos. Sci. 73, 3719-3737 (2016).

128. Agard, V. \& Emanuel, K. Clausius-Clapeyron scaling of peak CAPE in continental convective storm environments. J. Atmos. Sci. 74, 3043-3054 (2017).

129. Singh, M. S., Kuang, Z., Maloney, E. D., Hannah, W. M. \& Wolding, B. O. Increasing potential for intense tropical and subtropical thunderstorms under global warming. Proc. Natl. Acad. Sci. U. S. A. 114, 11657-11662 (2017).

130. Romps, D. M. Response of tropical precipitation to global warming. J. Atmos. Sci. 68, 123-138 (2011).

131. Muller, C. J., O'Gorman, P. A. \& Back, L. E. Intensification of precipitation extremes with warming in a cloud-resolving model. J. Clim. 24, 2784-2800 (2011).

132. Li, Y. et al. Strong intensification of hourly rainfall extremes by urbanization. Geophys. Res. Lett. (2020) doi:10.1029/2020gl088758.

133. Byrne, M. P. \& O'Gorman, P. A. Understanding Decreases in Land Relative Humidity with Global Warming: Conceptual Model and GCM Simulations. J. Clim. 29, 9045-9061 (2016).

134. Chen, J., Dai, A., Zhang, Y. \& Rasmussen, K. L. Changes in Convective Available Potential Energy and Convective Inhibition under Global Warming. J. Clim. 33, 2025-2050 (2020).

135. Bryan, G. H. \& Morrison, H. Sensitivity of a Simulated Squall Line to Horizontal Resolution and Parameterization of Microphysics. Mon. Weather Rev. 140, 202-225 (2012).

136. Varble, A. et al. Evaluation of cloud-resolving and limited area model intercomparison simulations using twp-ice observations: 1. deep convective updraft properties. J. Geophys. Res. 119, 13891-13918 (2014).

137. Fan, J., Ruby Leung, L., Rosenfeld, D. \& Demott, P. J. Effects of cloud condensation nuclei and ice nucleating particles on precipitation processes and supercooled liquid in mixed-phase orographic clouds. Atmos. Chem. Phys. 17, 1017-1035 (2017).

138. Lebo, Z. J. \& Morrison, H. Effects of horizontal and vertical grid spacing on mixing in simulated squall lines and implications for convective strength and structure. Mon. Weather Rev. 143, 43554375 (2015).

139. Grabowski, W. W. \& Prein, A. F. Separating Dynamic and Thermodynamic Impacts of Climate Change on Daytime Convective Development over Land. J. Clim. 32, 5213-5234 (2019).

140. Prein, A. F. \& Heymsfield, A. J. Increased melting level height impacts surface precipitation phase and intensity. Nat. Clim. Chang. 10, 771-776 (2020).

141. Trapp, R. J., Hoogewind, K. A. \& Lasher-Trapp, S. Future changes in hail occurrence in the United States determined through convection-permitting dynamical downscaling. J. Clim. 32, 5493-5509 (2019).

142. Singh, M. S. \& O'Gorman, P. A. Influence of microphysics on the scaling of precipitation extremes with temperature. Geophys. Res. Lett. 41, 6037-6044 (2014).

143. Narsey, S. et al. Convective Precipitation Efficiency Observed in the Tropics. Geophys. Res. Lett. 46, 13574-13583 (2019).

144. Lutsko, N. J. \& Cronin, T. W. Increase in Precipitation Efficiency With Surface Warming in Radiative-Convective Equilibrium. J. Adv. Model. Earth Syst. 10, 2992-3010 (2018).

145. Tompkins, A. M. \& Tompkins, A. M. Organization of Tropical Convection in Low Vertical Wind Shears: The Role of Cold Pools. http://dx.doi.org/10.1175/15200469(2001)058<1650:OOTCIL > 2.0.CO;2 (2001) doi:10.1175/15200469(2001)058<1650:OOTCIL $>2.0$. CO;2.

146. Droegemeier, K. K., Wilhelmson, R. B., Droegemeier, K. K. \& Wilhelmson, R. B. ThreeDimensional Numerical Modeling of Convection Produced by Interacting Thunderstorm 
Outflows. Part I: Control Simulation and Low-Level Moisture Variations.

http://dx.doi.org/10.1175/1520-0469(1985)042<2381:TDNMOC>2.0.CO;2 (1985)

doi:10.1175/1520-0469(1985)042<2381:TDNMOC $>2.0 . C O ; 2$.

147. Schlemmer, L. \& Hohenegger, C. The Formation of Wider and Deeper Clouds as a Result of Cold-Pool Dynamics. J. Atmos. Sci. 71, 2842-2858 (2014).

148. Haerter, J. O., Böing, S. J., Henneberg, O. \& Nissen, S. B. Circling in on Convective Organization. Geophys. Res. Lett. 46, 7024-7034 (2019).

149. Weisman, M. L. \& Rotunno, R. '“A Theory for Strong Long-Lived Squall Lines”' Revisited. Journal of the Atmospheric Sciences vol. $61 \mathrm{http}: / /$ journals.ametsoc.org/jas/articlepdf/61/4/361/3476602/1520-0469 (2004).

150. Brooks, H. E. Severe thunderstorms and climate change. Atmospheric Research vol. 123 129-138 (2013).

151. Vecchi, G. A. \& Soden, B. J. Global warming and the weakening of the tropical circulation. J. Clim. 20, 4316-4340 (2007).

152. Moseley, C., Hohenegger, C., Berg, P. \& Haerter, J. O. Intensification of convective extremes driven by cloud-cloud interaction. Nat. Geosci. 9, 748-752 (2016).

153. Glenn, I. B. \& Krueger, S. K. Connections matter: Updraft merging in organized tropical deep convection. Geophys. Res. Lett. 44, 7087-7094 (2017).

154. Loriaux, J. M., Lenderink, G. \& Pier Siebesma, A. Large-scale controls on extreme precipitation. J. Clim. 30, 955-968 (2017).

155. Haerter, J. O., Berg, P. \& Moseley, C. Precipitation onset as the temporal reference in convective self-organization. Geophys. Res. Lett. 44, 6450-6459 (2017).

156. Molnar, P., Fatichi, S., Gaál, L., Szolgay, J. \& Burlando, P. Storm type effects on super ClausiusClapeyron scaling of intense rainstorm properties with air temperature. Hydrol. Earth Syst. Sci. 19, 1753-1766 (2015).

157. Scoccimarro, E. et al. Projected Changes in Intense Precipitation over Europe at the Daily and Subdaily Time Scales. J. Clim. 28, 6193-6203 (2015).

158. Pendergrass, A. G., Reed, K. A. \& Medeiros, B. The link between extreme precipitation and convective organization in a warming climate: Global radiative-convective equilibrium simulations. Geophys. Res. Lett. 43, 11,445-11,452 (2016).

159. Peleg, N. et al. Intensification of Convective Rain Cells at Warmer Temperatures Observed from High-Resolution Weather Radar Data. J. Hydrometeorol. 19, 715-726 (2018).

160. Lochbihler, K., Lenderink, G. \& Siebesma, A. P. Response of Extreme Precipitating Cell Structures to Atmospheric Warming. J. Geophys. Res. Atmos. 124, 6904-6918 (2019).

161. Kröner, N. et al. Separating climate change signals into thermodynamic, lapse-rate and circulation effects: theory and application to the European summer climate. Clim. Dyn. 48, 3425-3440 (2017).

162. Loriaux, J. M., Lenderink, G. \& Pier Siebesma, A. Peak precipitation intensity in relation to atmospheric conditions and large-scale forcing at midlatitudes. J. Geophys. Res. 121, 5471-5487 (2016).

163. Baker, H. S. et al. Higher $\mathrm{CO} 2$ concentrations increase extreme event risk in a $1.5^{\circ} \mathrm{c}$ world. Nat. Clim. Chang. 8, 604-608 (2018).

164. Fan, J. et al. Substantial convection and precipitation enhancements by ultrafine aerosol particles. Science (80-. ). 359, 411-418 (2018).

165. Lin, L. et al. Changes in Extreme Rainfall Over India and China Attributed to Regional AerosolCloud Interaction During the Late 20th Century Rapid Industrialization. Geophys. Res. Lett. 45, 7857-7865 (2018).

166. Sillmann, J., Stjern, C. W., Myhre, G. \& Forster, P. M. Slow and fast responses of mean and extreme precipitation to different forcing in CMIP5 simulations. Geophys. Res. Lett. 44, 63836390 (2017).

167. Lee, S. S., Guo, J. \& Li, Z. Delaying precipitation by air pollution over the Pearl River Delta: 2 . 
Model simulations. J. Geophys. Res. 121, 11739-11760 (2016).

168. Grabowski, W. W. Can the impact of aerosols on deep convection be isolated from meteorological effects in atmospheric observations? J. Atmos. Sci. 75, 3347-3363 (2018).

169. Santer, B. D. et al. Contributions of anthropogenic and natural forcing to recent tropopause height changes. Science (80-. ). 301, 479-483 (2003).

170. Finney, D. L. et al. Effects of Explicit Convection on Future Projections of Mesoscale Circulations, Rainfall, and Rainfall Extremes over Eastern Africa. J. Clim. 33, 2701-2718 (2020).

171. Gagin, A., Rosenfeld, D. \& López, R. E. The Relationship between Height and Precipitation Characteristics of Summertime Convective Cells in South Florida. Journal of the Atmospheric Sciences vol. 42 http://journals.ametsoc.org/jas/article-pdf/42/1/84/3422899/1520-0469 (1985).

172. Berg, A. et al. Land-atmosphere feedbacks amplify aridity increase over land under global warming. Nat. Clim. Chang. 6, 869-874 (2016).

173. Barbero, R., Abatzoglou, J. T. \& Fowler, H. J. Contribution of large-scale midlatitude disturbances to hourly precipitation extremes in the United States. Clim. Dyn. 52, 197-208 (2019).

174. Lamjiri, M. A., Dettinger, M. D., Ralph, F. M. \& Guan, B. Hourly storm characteristics along the U.S. West Coast: Role of atmospheric rivers in extreme precipitation. Geophys. Res. Lett. 44, 7020-7028 (2017).

175. Payne, A. E. et al. Responses and impacts of atmospheric rivers to climate change. Nat. Rev. Earth Environ. 1, 143-157 (2020).

176. Moron, V., Barbero, R., Evans, J. P., Westra, S. \& Fowler, H. J. Weather types and hourly to multiday rainfall characteristics in tropical Australia. J. Clim. 32, (2019).

177. Berghuijs, W. R., Harrigan, S., Molnar, P., Slater, L. J. \& Kirchner, J. W. The Relative Importance of Different Flood-Generating Mechanisms Across Europe. Water Resour. Res. 55, 4582-4593 (2019).

178. Do, H. X., Westra, S., Leonard, M. \& Gudmundsson, L. Global-Scale Prediction of Flood Timing Using Atmospheric Reanalysis. Water Resour. Res. 56, (2020).

179. Merz, R. \& Blöschl, G. A process typology of regional floods. Water Resour. Res. 39, (2003).

180. Tarasova, L. et al. Causative classification of river flood events. Wiley Interdiscip. Rev. Water $\mathbf{6}$, e1353 (2019).

181. Lenggenhager, S., Croci-Maspoli, M., Brönnimann, S. \& Martius, O. On the dynamical coupling between atmospheric blocks and heavy precipitation events: A discussion of the southern Alpine flood in October 2000. Q. J. R. Meteorol. Soc. 145, 530-545 (2019).

182. Nikumbh, A. C., Chakraborty, A. \& Bhat, G. S. Recent spatial aggregation tendency of rainfall extremes over India. Sci. Rep. 9, 1-7 (2019).

183. Zanardo, S., Nicotina, L., Hilberts, A. G. J. \& Jewson, S. P. Modulation of Economic Losses From European Floods by the North Atlantic Oscillation. Geophys. Res. Lett. 46, 2563-2572 (2019).

184. Terti, G., Ruin, I., Anquetin, S. \& Gourley, J. J. A Situation-Based Analysis of Flash Flood Fatalities in the United States. Bull. Am. Meteorol. Soc. 98, 333-345 (2017).

185. III, C. A. D. et al. Flash Flood Forecasting: An Ingredients-Based Methodology. http://dx.doi.org/10.1175/1520-0434(1996)011<0560:FFFAIB>2.0.CO;2 (1996) doi:10.1175/1520-0434(1996)011<0560:FFFAIB >2.0.CO;2.

186. Hapuarachchi, H. A. P., Wang, Q. J. \& Pagano, T. C. A review of advances in flash flood forecasting. Hydrol. Process. 25, 2771-2784 (2011).

187. Johnson, F. et al. Natural hazards in Australia: floods. Clim. Change 139, 21-35 (2016).

188. Eekhout, J. P. C., Hunink, J. E., Terink, W. \& de Vente, J. Why increased extreme precipitation under climate change negatively affects water security. Hydrol. Earth Syst. Sci. 22, 5935-5946 (2018).

189. Kirchner, J. W. Catchments as simple dynamical systems: Catchment characterization, rainfallrunoff modeling, and doing hydrology backward. Water Resour. Res. 45, (2009).

190. Blöschl, G. et al. Changing climate both increases and decreases European river floods. Nature vol. 573 108-111 (2019). 
191. Rajah, K. et al. Changes to the temporal distribution of daily precipitation. Geophys. Res. Lett. 41, 8887-8894 (2014).

192. Bennett, B., Leonard, M., Deng, Y. \& Westra, S. An empirical investigation into the effect of antecedent precipitation on flood volume. J. Hydrol. 567, 435-445 (2018).

193. Sharma, A., Wasko, C. \& Lettenmaier, D. P. If Precipitation Extremes Are Increasing, Why Aren't Floods? Water Resources Research vol. 54 8545-8551 (2018).

194. Wasko, C. \& Nathan, R. Influence of changes in rainfall and soil moisture on trends in flooding. $J$. Hydrol. 575, 432-441 (2019).

195. Musselman, K. N. et al. Projected increases and shifts in rain-on-snow flood risk over western North America. Nature Climate Change vol. 8 808-812 (2018).

196. Ward, P. J. et al. Dependence between high sea-level and high river discharge increases flood hazard in global deltas and estuaries. Environ. Res. Lett. 13, 084012 (2018).

197. Wu, W. et al. Mapping Dependence Between Extreme Rainfall and Storm Surge. J. Geophys. Res. Ocean. 123, 2461-2474 (2018).

198. Bevacqua, E. et al. Higher probability of compound flooding from precipitation and storm surge in Europe under anthropogenic climate change. Sci. Adv. 5, eaaw5531 (2019).

199. Leonard, M. et al. A compound event framework for understanding extreme impacts. Wiley Interdisciplinary Reviews: Climate Change vol. 5 113-128 (2014).

200. Zscheischler, J. et al. Future climate risk from compound events. Nature Climate Change vol. 8 469-477 (2018).

201. Do, H. X., Westra, S. \& Leonard, M. A global-scale investigation of trends in annual maximum streamflow. J. Hydrol. 552, 28-43 (2017).

202. Erlingis, J. M., Gourley, J. J. \& Basara, J. B. Diagnosing moisture sources for flash floods in the United States. Part II: Terrestrial and oceanic sources of moisture. J. Hydrometeorol. 20, 15111531 (2019).

203. Do, H. X., Gudmundsson, L., Leonard, M. \& Westra, S. The Global Streamflow Indices and Metadata Archive - Part 1: Station catalog and Catchment boundary. (2018) doi:10.1594/PANGAEA.887477.

204. Villarini, G. et al. Flood frequency analysis for nonstationary annual peak records in an urban drainage basin. Adv. Water Resour. 32, 1255-1266 (2009).

205. Arnell, N. W. \& Gosling, S. N. The impacts of climate change on river flood risk at the global scale. Clim. Change 134, 387-401 (2016).

206. Dankers, R. et al. First look at changes in flood hazard in the Inter-Sectoral Impact Model Intercomparison Project ensemble. Proc. Natl. Acad. Sci. U. S. A. 111, 3257-3261 (2014).

207. Do, H. X. et al. Historical and future changes in global flood magnitude \&amp;ndash; evidence from a model-observation investigation. Hydrol. Earth Syst. Sci. Discuss. 1-31 (2019) doi:10.5194/hess-2019-388.

208. Hirabayashi, Y. et al. Global flood risk under climate change. Nat. Clim. Chang. 3, 816-821 (2013).

209. Morrison, A., Villarini, G., Zhang, W. \& Scoccimarro, E. Projected changes in extreme precipitation at sub-daily and daily time scales. Glob. Planet. Change 182, (2019).

210. Döll, P., Douville, H., Güntner, A., Müller Schmied, H. \& Wada, Y. Modelling Freshwater Resources at the Global Scale: Challenges and Prospects. Surveys in Geophysics vol. 37 195-221 (2016).

211. Wada, Y. et al. Human-water interface in hydrological modelling: Current status and future directions. Hydrol. Earth Syst. Sci. 21, 4169-4193 (2017).

212. Alexander, K., Hettiarachchi, S., Ou, Y. \& Sharma, A. Can integrated green spaces and storage facilities absorb the increased risk of flooding due to climate change in developed urban environments? J. Hydrol. 579, 124201 (2019).

213. Hettiarachchi, S., Wasko, C. \& Sharma, A. Increase in flood risk resulting from climate change in a developed urban watershed - The role of storm temporal patterns. Hydrol. Earth Syst. Sci. 22, 
2041-2056 (2018).

214. Beck, H. E. et al. MSWEP: 3-hourly $0.25^{\circ}$ global gridded precipitation (1979-2015) by merging gauge, satellite, and reanalysis data. Hydrol. Earth Syst. Sci. 21, 589-615 (2017).

215. Beck, H. E. et al. MSWep v2 Global 3-hourly $0.1^{\circ}$ precipitation: Methodology and quantitative assessment. Bull. Am. Meteorol. Soc. 100, 473-500 (2019).

216. Coppola, E. et al. A first-of-its-kind multi-model convection permitting ensemble for investigating convective phenomena over Europe and the Mediterranean. Clim. Dyn. (2018) doi:10.1007/s00382-018-4521-8.

217. Meredith, E. P., Ulbrich, U. \& Rust, H. W. The Diurnal Nature of Future Extreme Precipitation Intensification. Geophys. Res. Lett. 46, 7680-7689 (2019).

218. Allan, R. P. et al. Advances in understanding large-scale responses of the water cycle to climate change. Ann. N. Y. Acad. Sci. (2020) doi:10.1111/nyas.14337.

\section{In Press}

Prein AF, Rasmussen RM, Wang D., Giangrande S. (accepted) Sensitivity of Organized Convective Storms to Model Grid Spacing in Current and Future Climates. Philosophical Transactions of the Royal Society A. 


\section{Supporting Information}

\begin{tabular}{|c|c|}
\hline 1 & Burn et al. (2011) \\
\hline 2 & Mekis et al. (2015) \\
\hline 3 & Shephard et al. (2014) \\
\hline 4 & Barbero et al. (2017) \\
\hline 5 & Yu et al. (2016) \\
\hline 6 & Muschinski and Katz (2013) \\
\hline 7 & Singer and Michaelides (2017) \\
\hline 8 & Smith (2015) \\
\hline 9 & Brown et al. (2019) \\
\hline 10 & Ochoa et al. (2015) \\
\hline 11 & Kendon et al. (2018) \\
\hline 12 & Paulson (2010) \\
\hline 13 & Kiely (1999) \\
\hline 14 & Leahy and Kiely (2011) \\
\hline 15 & Saidi et al. (2013) \\
\hline 16 & Saidi et al. (2015) \\
\hline 17 & Acquaotta et al., (2018) \\
\hline 18 & Merino et al., (2018) \\
\hline 19 & Vallebona et al. (2015) \\
\hline 20 & Soldini and Darvini (2017) \\
\hline 21 & Arnone et al. (2013) \\
\hline 22 & Bonaccorso and Aronica (2016) \\
\hline
\end{tabular}




\begin{tabular}{|c|c|}
\hline 23 & Lenderink et al. (2011) \\
\hline 24 & Madsen et al. (2009) \\
\hline 25 & Hanel et al. (2016) \\
\hline 26 & Busuioc et al. (2017) \\
\hline 27 & De Toffol et al. (2009) \\
\hline 28 & Sen Roy and Rouault (2013) \\
\hline 29 & Du Plessis and Burger (2015) \\
\hline 30 & Kant (2018) \\
\hline 31 & Sen Roy (2009) \\
\hline 32 & Deshpande et al. (2012) \\
\hline 33 & Syafrina et al. (2015) \\
\hline 34 & Li et al. (2020) \\
\hline 35 & Beck et al. (2015) \\
\hline 36 & Siswanto et al. (2016) \\
\hline 37 & Liang and Ding (2017) \\
\hline 38 & Jun et al. (2019) \\
\hline 39 & Fujibe et al. (2005) \\
\hline 40 & Kanae et al. (2004) \\
\hline 41 & Xaio et al. (2016) \\
\hline 42 & Yu et al. (2010) \\
\hline 43 & Zhang and Zhai (2011) \\
\hline 44 & Yu and Li (2012) \\
\hline 45 & Li et al. (2016) \\
\hline 46 & Shiu et al. (2009) \\
\hline
\end{tabular}




\begin{tabular}{|l|l|}
\hline 47 & Wu et al. (2019) \\
\hline 48 & Jakob et al. (2011) \\
\hline 49 & Westra and Sisson (2011) \\
\hline 50 & Chen et al. (2013a) \\
\hline 51 & Laz et al. (2014) \\
\hline 52 & Chen et al. (2013b) \\
\hline 53 & Zheng et al. (2015) \\
\hline 54 & Hajani et al. (2017) \\
\hline 55 & Guerreiro et al. (2018) \\
\hline
\end{tabular}

Table S1: Corresponding references associated with studies of sub-daily rainfall trends shown in Figure 3. Numbers correspond to the reference index for each study.

\section{References}

Acquaotta, F., Faccini, F., Fratianni, S., Paliaga, G. and Sacchini, A., 2018: Rainfall intensity in the Genoa Metropolitan Area: secular variations and consequences. Weather, 73, 356-362.

Arnone, E., D. Pumo, F. Viola, L. V. Noto, and G. La Loggia, 2013: Rainfall statistics changes in Sicily. Hydrol. Earth Syst. Sci., 17, 2449-2458.

Barbero, R., H. J. Fowler, G. Lenderink, and S. Blenkinsop, 2017: Is the intensification of precipitation extremes with global warming better detected at hourly than daily resolutions? Geophysical Research Letters, 44, 974-983.

Beck, F., A. Bárdossy, J. Seidel, T. Müller, E. Fernandez Sanchis, and A. Hauser, 2015: Statistical analysis of sub-daily precipitation extremes in Singapore. Journal of Hydrology: Regional Studies, $3,337-358$.

Brown, V.M., B.D. Keim, and A.W. Black, 2019: Climatology and Trends in Hourly Precipitation for the Southeast United States. J. Hydrometeor., 20, 1737-1755.

Bonaccorso, B., and G. T. Aronica, 2016: Estimating Temporal Changes in Extreme Rainfall in Sicily Region (Italy). Water Resources Management, 30, 5651-5670.

Busuioc, A., Baciu, M., Breza, T., Dumitrescu, A., Stoica, C., and N. Baghina, 2017: Changes in intensity of high temporal resolution precipitation extremes in Romania: Implications for ClausiusClapeyron scaling. Climate Research, 72, 239-249.

Burn, D. H., R. Mansour, K. Zhang, and P. H. Whitfield, 2011: Trends and Variability in Extreme Rainfall Events in British Columbia. Canadian Water Resources Journal / Revue canadienne des ressources hydriques, 36, 67-82. 
Chen, Y.-R., B. Yu, and G. Jenkins, 2013a: Secular Variation in Rainfall Intensity and Temperature in Eastern Australia. Journal of Hydrometeorology, 14, 1356-1363.

Chen, Y.-R., B. Yu, and G. Jenkins, 2013b: Secular variation in rainfall and intensity-frequency-duration curves in Eastern Australia. Journal of Water and Climate Change, 4, 244-251.

De Toffol, S., A. N. Laghari, and W. Rauch, 2009: Are extreme rainfall intensities more frequent? Analysis of trends in rainfall patterns relevant to urban drainage systems. Water Sci. Technol., 59, 1769-1776.

Deshpande, N. R., A. Kulkarni, and K. Krishna Kumar, 2012: Characteristic features of hourly rainfall in India. International Journal of Climatology, 32, 1730-1744.

Du Plessis, J. A. and Burger, G. J., 2015: Investigation into increasing short-duration rainfall intensities in South Africa. Water SA, 41, 416-424.

Fujibe, F., N. Yamazaki, M. Katsuyama, and K. Kobayashi, 2005: The Increasing Trend of Intense Precipitation in Japan Based on Four-hourly Data for a Hundred Years. SOLA, 1, 41-44.

Guerreiro, S. B., H.J. Fowler, R. Barbero, S. Westra, G. Lenderink, S. Blenkinsop, E. Lewis and X-F Li, 2018: Detection of continental-scale intensification of hourly rainfall extremes. Nature Climate Change, 8, 803-807.

Hajani, E., A. Rahman, and E. Ishak, 2017: Trends in extreme rainfall in the state of New South Wales, Australia. Hydrological Sciences Journal, 62, 2160-2174.

Hanel, M., A. Pavlásková, and J. Kyselý, 2016: Trends in characteristics of sub-daily heavy precipitation and rainfall erosivity in the Czech Republic. International Journal of Climatology, 36, 1833-1845.

Jakob, D., D. J. Karoly, and A. Seed, 2011: Non-stationarity in daily and sub-daily intense rainfall - Part 2: Regional assessment for sites in south-east Australia. Nat. Hazards Earth Syst. Sci., 11, 22732284.

Jun, C, Qin, X, Tung, Y $\square$ K, De Michele, C., 2019: On the statistical analysis of rainstorm events between historical (1777-1907) and modern (1961-2010) periods in Seoul, Korea. Int J Clim., in press.

Kanae, S., T. Oki, and A. Kashida, 2004: Changes in Hourly Heavy Precipitation at Tokyo from 1890 to 1999. Journal of the Meteorological Society of Japan. Ser. II, 82, 241-247.

Kant, S, 2018: Trend and variability of hourly intensity of rainfall over eastern and northern part of Uttar Pradesh during 1969-2014. Mausam, 69, 577-589.

Kendon, E. J., S. Blenkinsop, and H. J. Fowler, 2018: When will we detect changes in short-duration precipitation extremes? Journal of Climate, 31, 2945-2964.

Kiely, G., 1999: Climate change in Ireland from precipitation and streamflow observations. Advances in Water Resources, 23, 141-151.

Laz, O.U., Rahman A., Yilmaz A., and K. Haddad, 2014: Trends in sub-hourly, sub-daily and daily extreme rainfall events in eastern Australia. Journal of Water and Climate Change, 5, 667-675.

Leahy, P. G., and G. Kiely, 2011: Short Duration Rainfall Extremes in Ireland: Influence of Climatic Variability. Water Resources Management, 25, 987-1003. 
Lenderink, G., H. Y. Mok, T. C. Lee, and G. J. van Oldenborgh, 2011: Scaling and trends of hourly precipitation extremes in two different climate zones - Hong Kong and the Netherlands. Hydrol. Earth Syst. Sci., 15, 3033-3041.

Li, D., Sun, J., Fu, S., Wei, J., Wang, S., and F. Tian, 2016: Spatiotemporal characteristics of hourly precipitation over central eastern China during the warm season of 1982-2012 Int. J. Clim., 36, 3148-3160.

Li, Y., H.J. Fowler, D. Argüeso, S. Blenkinsop, J.P. Evans, G. Lenderink, X. Yan, S.B. Guerreiro, E. Lewis, X-F Li, 2020: Strong intensification of hourly rainfall extremes by urbanization. Geophysical Research Letters, in revision.

Liang, P., and Ding, Y. 2017: The long-term variation of extreme heavy precipitation and its link to urbanization effects in Shanghai during 1916-2014. Advances in Atmospheric Sciences, 34, 321334.

Madsen, H., K. Arnbjerg-Nielsen, and P. S. Mikkelsen, 2009: Update of regional intensity-durationfrequency curves in Denmark: Tendency towards increased storm intensities. Atmospheric Research, 92, 343-349.

Mekis, É., L. A. Vincent, M. W. Shephard, and X. Zhang, 2015: Observed Trends in Severe Weather Conditions Based on Humidex, Wind Chill, and Heavy Rainfall Events in Canada for 1953-2012. Atmosphere-Ocean, 53, 383-397.

Merino, A., Fernández $\square$ González, S., García $\square$ Ortega, E., Sánchez, J.L., López, L. and Gascón, E., 2018: Temporal continuity of extreme precipitation events using sub $\square$ daily precipitation: application to floods in the Ebro basin, northeastern Spain. Int. J. Climatol, 38, 1877-1892.

Muschinski, T., and J. I. Katz, 2013: Trends in hourly rainfall statistics in the United States under a warming climate. Nature Climate Change, 3, 577.

Ochoa, C.A., A.I. Quintanar, G.B. Raga, and D. Baumgardner, 2015: Changes in Intense Precipitation Events in Mexico City. J. Hydrometeor., 16, 1804-1820.

Paulson, K. S., 2010: Trends in the incidence of rain rates associated with outages on fixed links operating above $10 \mathrm{GHz}$ in the southern United Kingdom. Radio Science, 45, RS1011.

Saidi, H., Ciampittiello, M., Dresti, C., and Ghiglieri, G., 2013: Observed variability and trends in extreme rainfall indices and Peaks-Over-Threshold series, Hydrol. Earth Syst. Sci. Discuss., 10, 6049-6079.

Saidi, H., Ciampittiello, M., Dresti, C., and G. Ghiglieri, 2015: Assessment of Trends in Extreme Precipitation Events: A Case Study in Piedmont (North-West Italy). Water Resources Management, 29, 63-80.

Sen Roy, S., 2009: A spatial analysis of extreme hourly precipitation patterns in India. International Journal of Climatology, 29, 345-355.

Sen Roy, S., and M. Rouault, 2013: Spatial patterns of seasonal scale trends in extreme hourly precipitation in South Africa. Applied Geography, 39, 151-157. 
Shephard, M. W., E. Mekis, R. J. Morris, Y. Feng, X. Zhang, K. Kilcup, and R. Fleetwood, 2014: Trends in Canadian Short $\square$ Duration Extreme Rainfall: Including an Intensity-Duration-Frequency Perspective. Atmosphere-Ocean, 52, 398-417.

Shiu, C.-J., S. C. Liu, and J.-P. Chen, 2009: Diurnally Asymmetric Trends of Temperature, Humidity, and Precipitation in Taiwan. Journal of Climate, 22, 5635-5649.

Singer, M. B. and K. Michaelides, 2017: Deciphering the expression of climate change within the Lower Colorado River basin by stochastic simulation of convective rainfall. Env. Res. Lett., 12, 104011.

Siswanto, S., van Oldenborgh, G.J., van der Schrier, G., Jilderda, R., van den Hurk, B., 2016. Temperature, extreme precipitation, and diurnal rainfall changes in the urbanized Jakarta city during the past 130 years. Int. J. Clim., 36, 3207-3225.

Smith, R.K. 2015: Changing rainfall and humidity within Southeast Texas. SpringerPlus 4, 449.

Soldini, L., and G. Darvini, 2017: Extreme rainfall statistics in the Marche region, Italy. Hydrology Research, 48, 686-700.

Syafrina, A. H., M. D. Zalina, and L. Juneng, 2015: Historical trend of hourly extreme rainfall in Peninsular Malaysia. Theoretical and Applied Climatology, 120, 259-285.

Vallebona, C., E. Pellegrino, P. Frumento, and E. Bonari, 2015: Temporal trends in extreme rainfall intensity and erosivity in the Mediterranean region: a case study in southern Tuscany, Italy. Climatic Change, 128, 139-151.

Westra, S., and S. A. Sisson, 2011: Detection of non-stationarity in precipitation extremes using a maxstable process model. Journal of Hydrology, 406, 119-128.

Wu, M., Y. Luo, F. Chen, and W.K. Wong, 2019: Observed Link of Extreme Hourly Precipitation Changes to Urbanization over Coastal South China. J. Appl. Meteor. Climatol., 58, 1799-1819.

Xiao, C., Wu, P., Zhang, L., Song, L., 2016: Robust increase in extreme summer rainfall intensity during the past four decades observed in China, Scientific Reports, 6, 38506.

Yu, L., S. Zhong, L. Pei, X. Bian, and W. E. Heilman, 2016: Contribution of large-scale circulation anomalies to changes in extreme precipitation frequency in the United States. Environmental Research Letters, 11, 044003.

Yu, R., and J. Li, 2012: Hourly Rainfall Changes in Response to Surface Air Temperature over Eastern Contiguous China. Journal of Climate, 25, 6851-6861.

Yu, R., J. Li, W. Yuan, and H. Chen, 2010: Changes in Characteristics of Late-Summer Precipitation over Eastern China in the Past 40 Years Revealed by Hourly Precipitation Data. Journal of Climate, 23, 3390-3396.

Zhang, H., and P. Zhai, 2011: Temporal and Spatial Characteristics of Extreme Hourly Precipitation over Eastern China in the Warm Season. Adv. Atmos. Sci., 28, 1177-1183.

Zheng, F., S. Westra, and M. Leonard, 2015: Opposing local precipitation extremes. Nature Climate Change, 5, 389. 



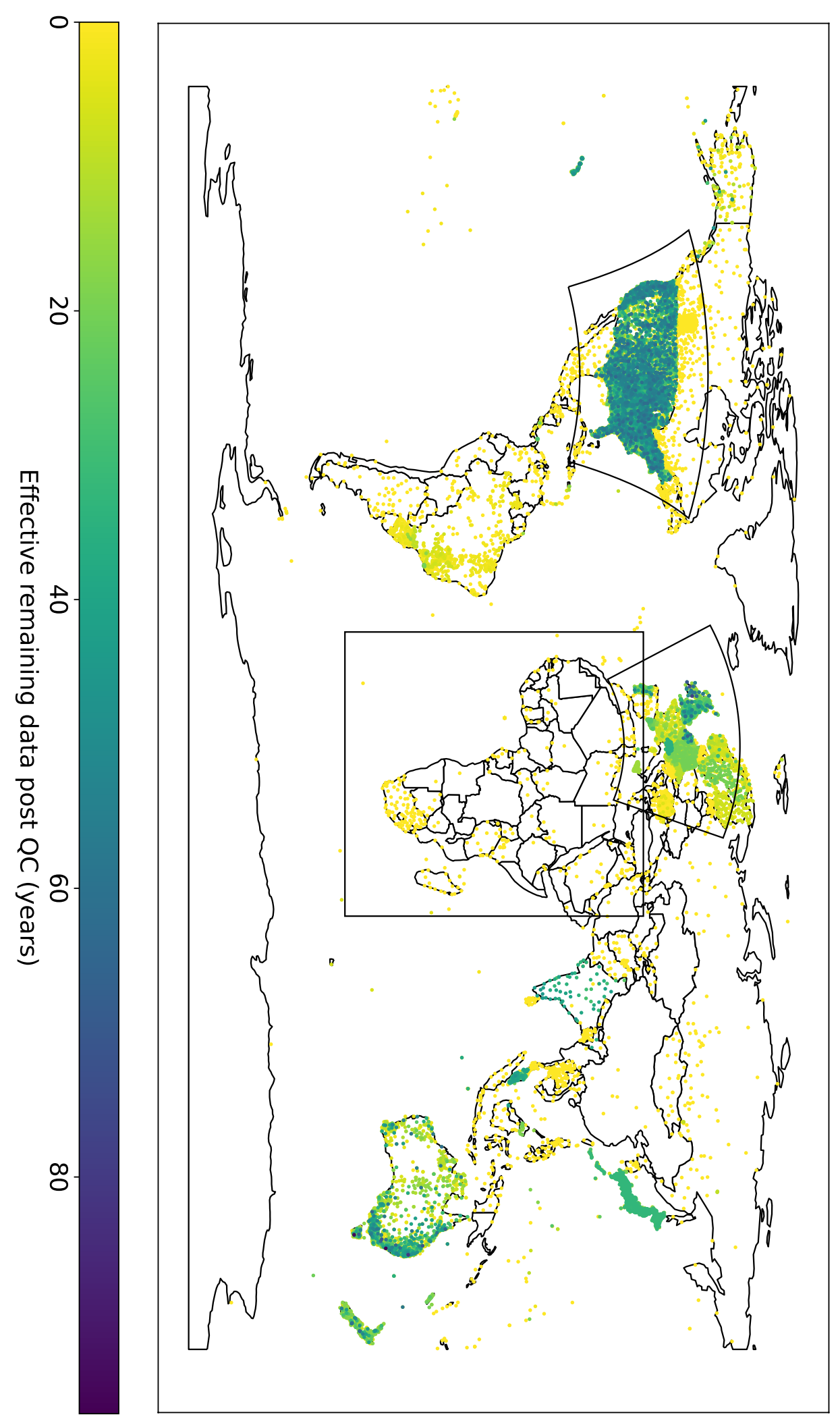



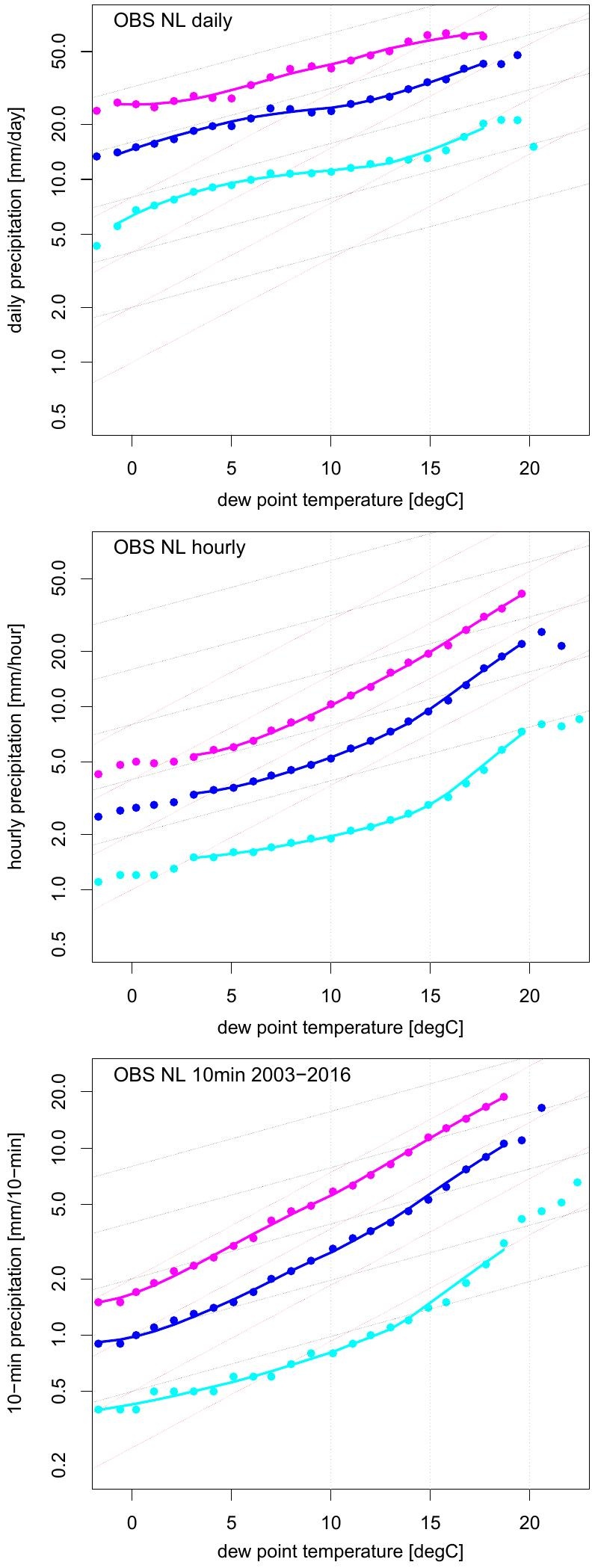
$\log P$

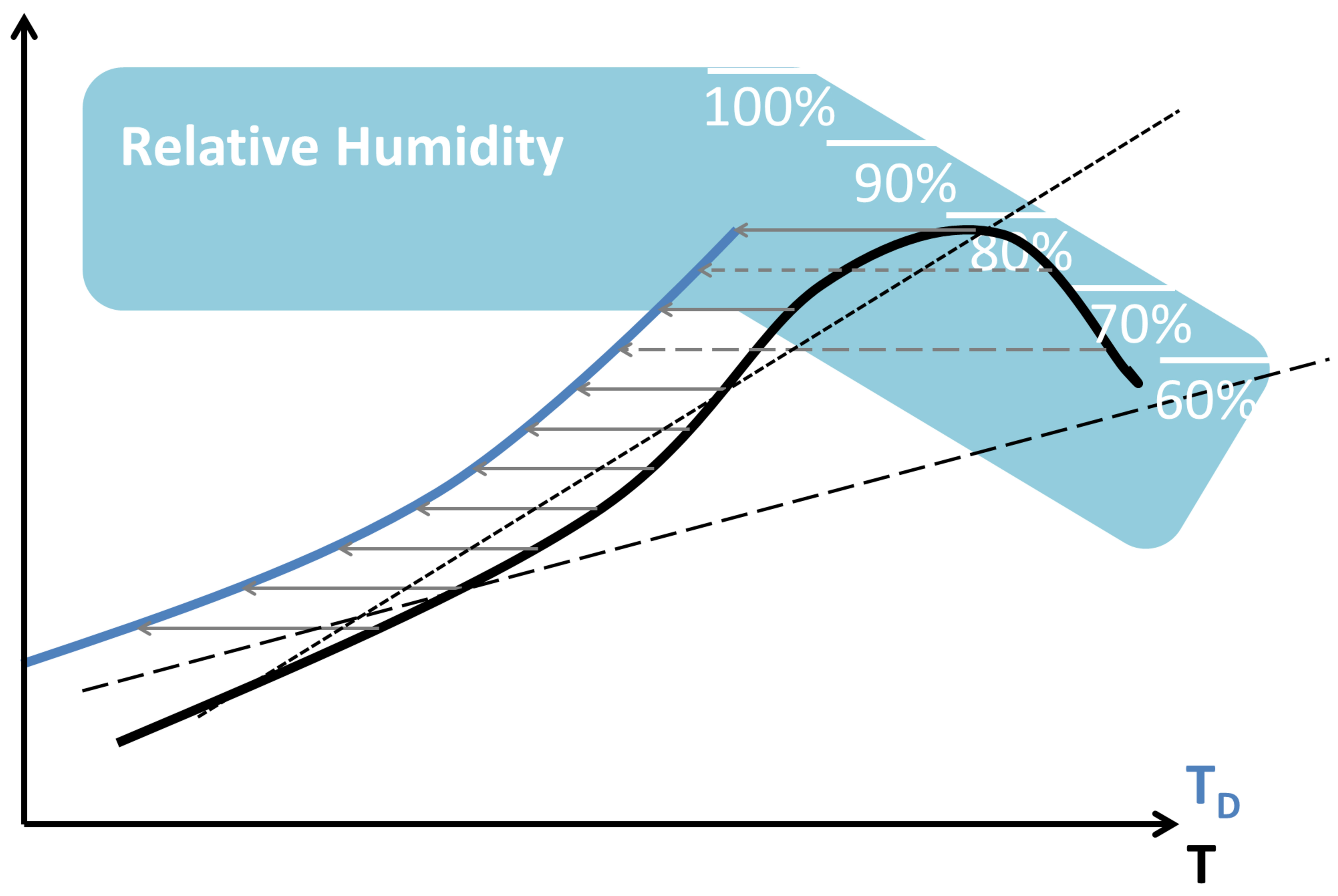

$\log P$

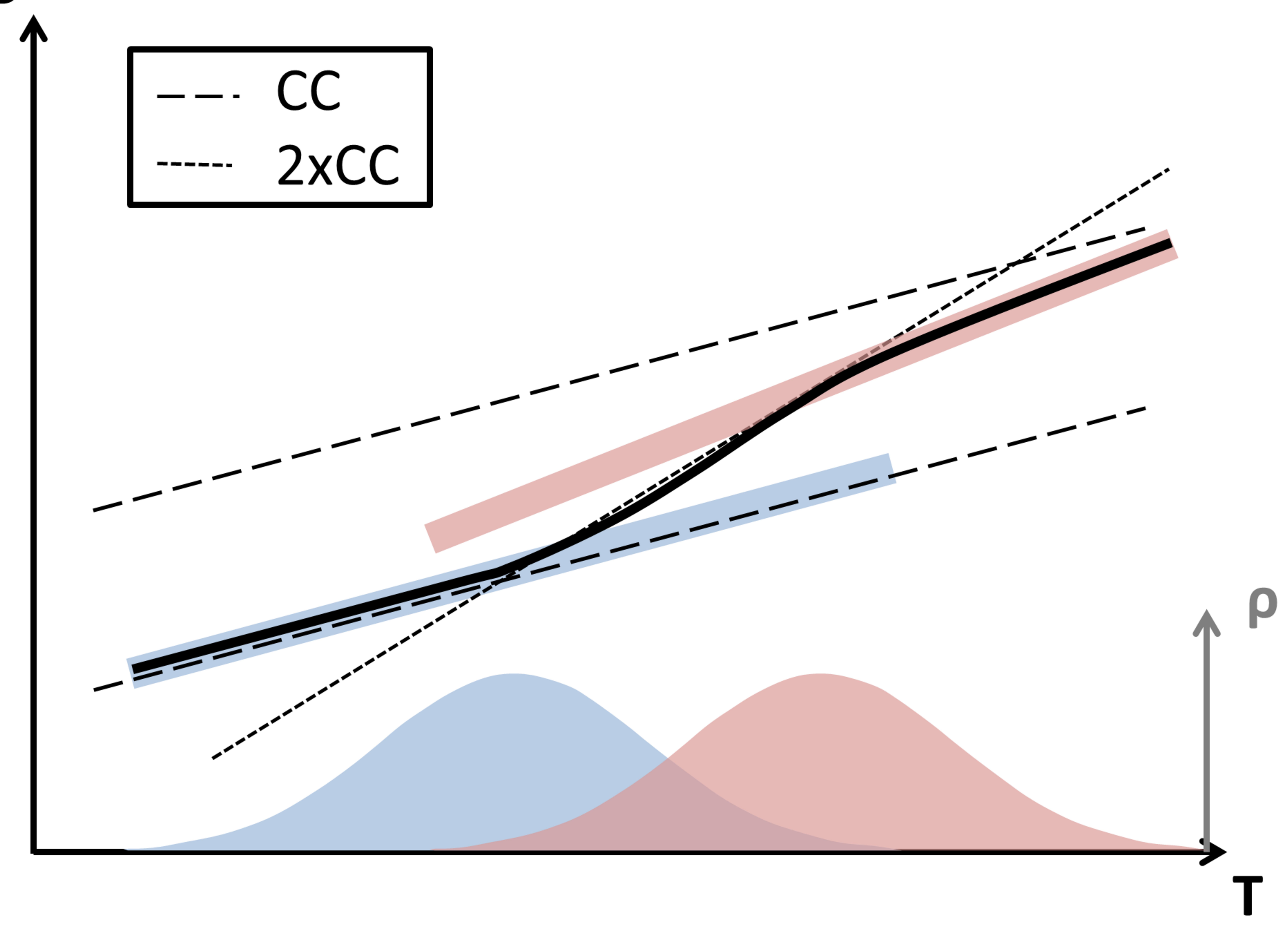




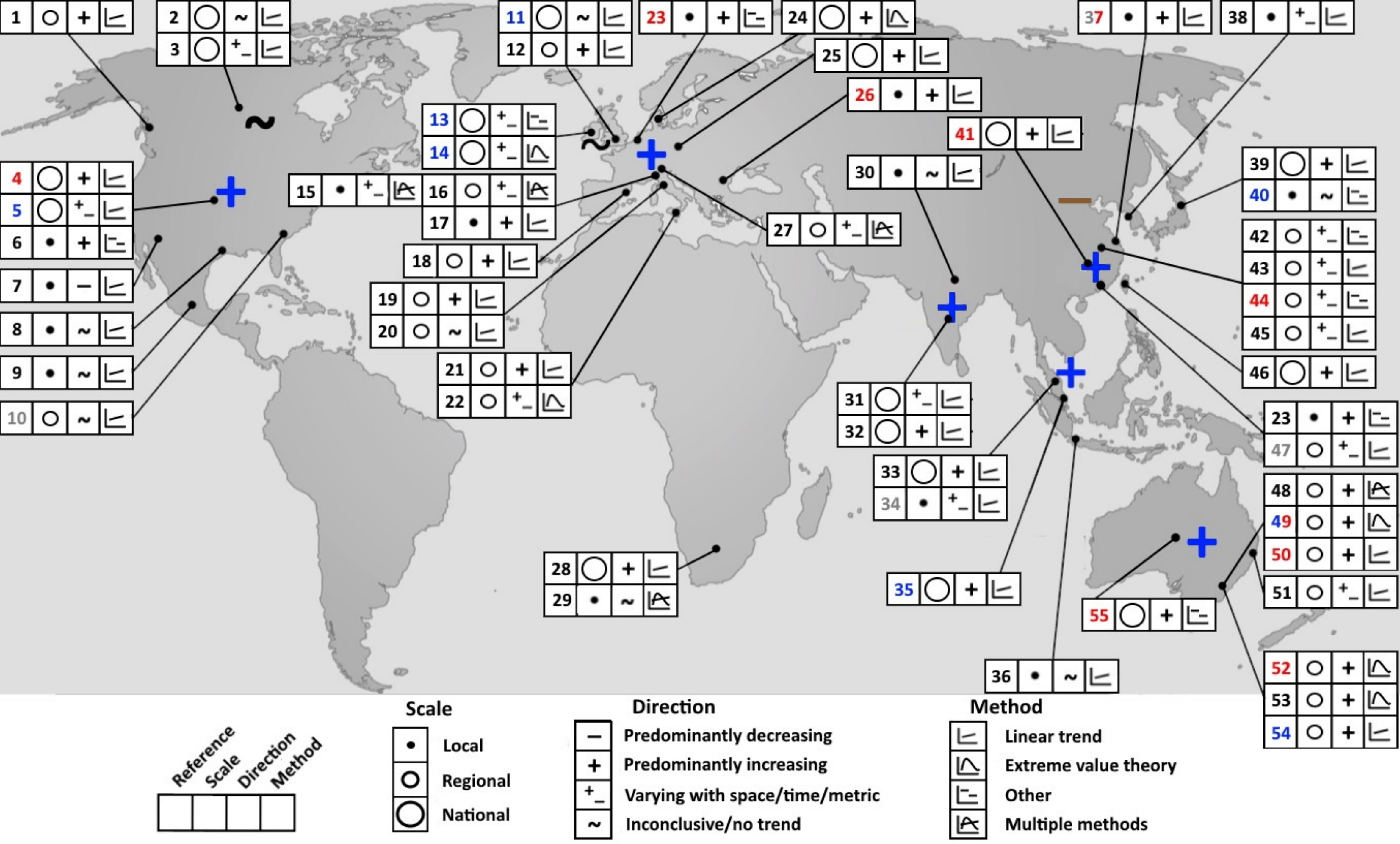




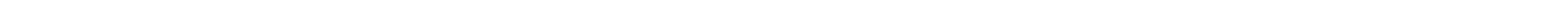


Changing location of wettest events reduces skill in observational detection and future projects of extreme precipitation at local scales (+/-)

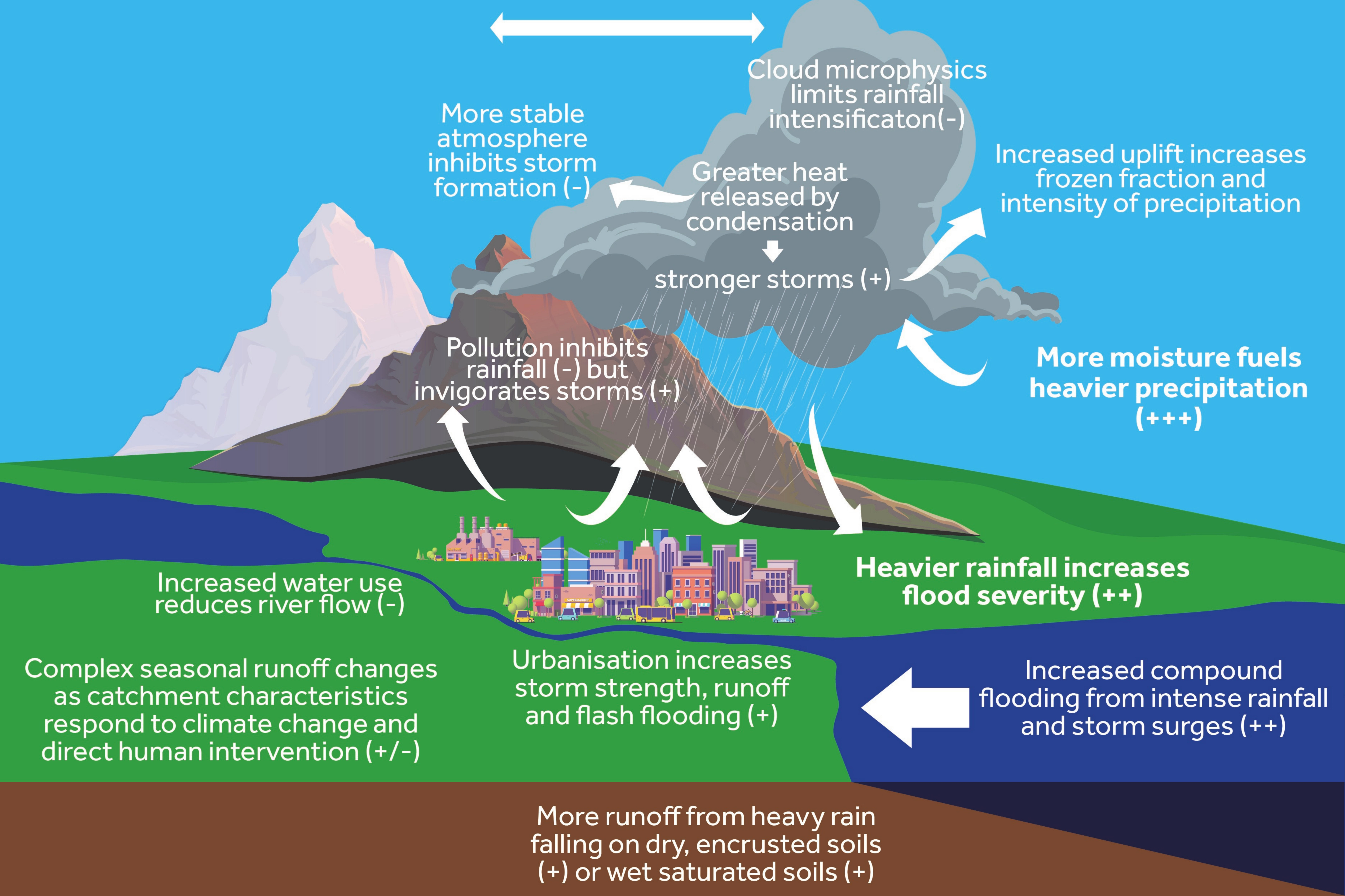

